\title{
القيم البمالية للصورة الفنيّة في شعر فتاة العرب عوشة
}

\section{السوبدي}

The aesthetic values of the artistic image in the poetry of the Arab girl Ausha Al-Suwaidi

\section{!}

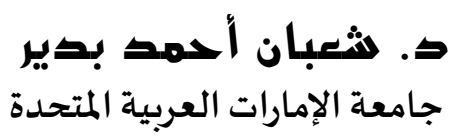

Doi: 10.12816/mdad.2021.152299

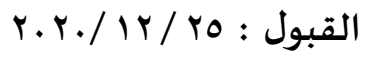

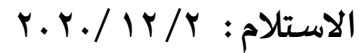

تهدف هذه الدراسة إلى الكثف عن القيم الجمالية للصورة الفنية في شعر عوشة

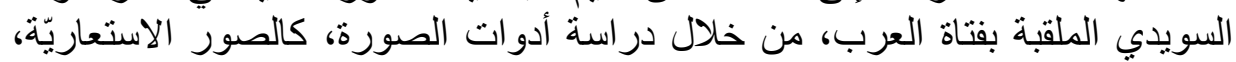

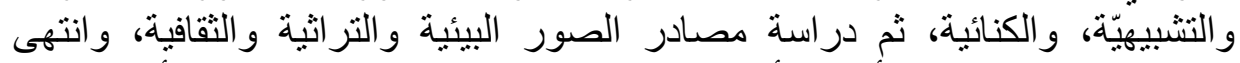
البحث إلى بعض النتائج أهمها: أن الصورة الفنية في شعر عوشة السويدي أدت ورئة وظيفة جمالية في نقل التجربة الذوقية إلى المتلقي، وكان لهاً أكبر الأثر في رقي اللغة الثية الثعرية،

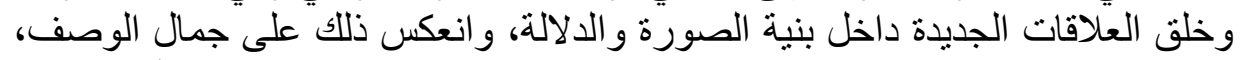
وجودة السبك، وحركية المعنى المبتكر بين التشخيص والتجسيم، وفئ، ومما أثرى القيم الجمالية في نص فتاة العرب ثراء المصادر التي استوحت منها عوشة عناصر صور صورها و وعانيها، بين التراث الإماراتي المتنوع و العريق، و المعاني والقيم الإسلامية، و البيئة

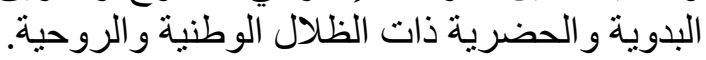

\section{Abstract:}

This study aims to reveal the aesthetic values of the artistic image in the poetry of Ousha Al-Suwaidi, dubbed the Girl of the Arabs, by studying image tools, such as allegorical, simulated, and metaphorical images, then studying the sources of environmental, heritage, and cultural images, and the research ended with some results, the most important of which are: The artistic image in 
Ousha Al-Suwaidi poetry performed an aesthetic function in transmitting the taste experience to the recipient, and it had the greatest impact on the advancement of the poetic language, and the creation of new relationships within the structure of the image and significance, and this was reflected in the beauty of the description, the quality of casting, and the movement of the innovative meaning between diagnosis and anthropomorphism, which enriched aesthetic values. In the text of Girl of the Arabs, the richness of the sources from which Ousha was inspired by the elements of her images and meanings, between the diverse and ancient Emirati heritage, Islamic meanings and values, and the Bedouin and urban environment of national and spiritual shades.

Keywords: Aesthetic values, poetry, Arab girl. Ousha, Al Suwaidi

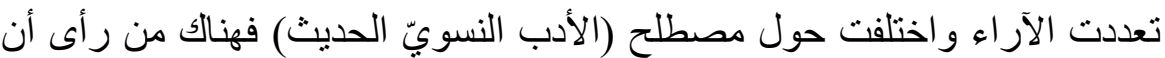
مقدمة:

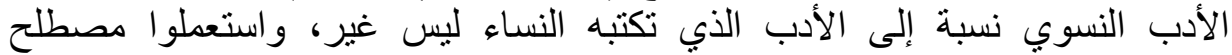

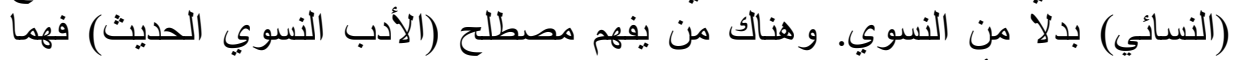

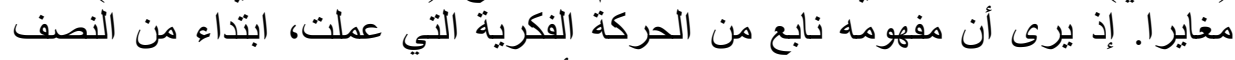

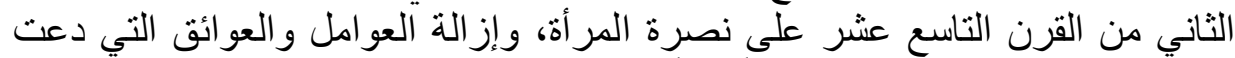

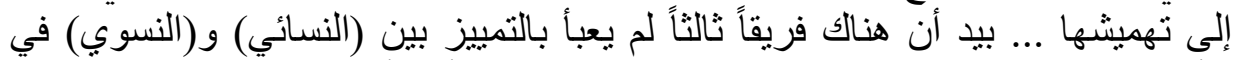

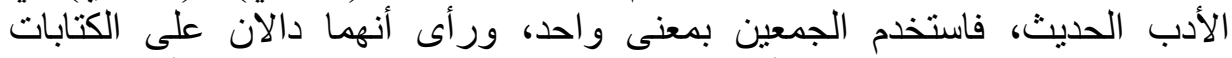
الإبداعية التي تعالج قضية المرأة من وجهة نظر التر الحركة النسوية، سواء أكان الكان الكاتب الكبات رجلا أم امر أثة.

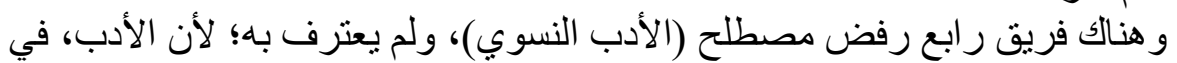

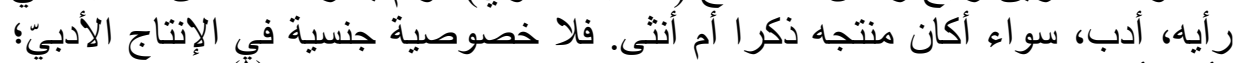

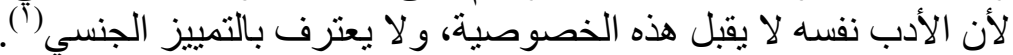

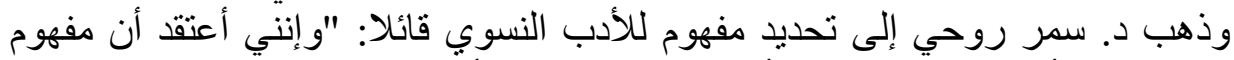

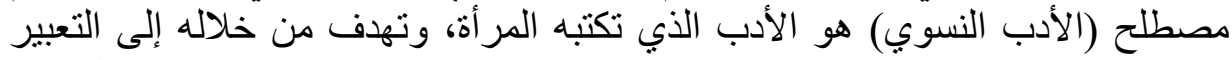

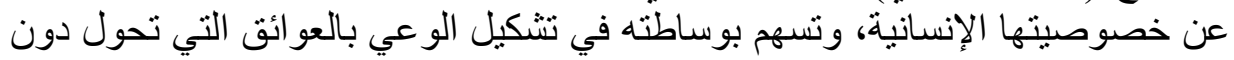

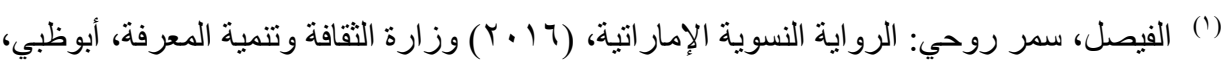




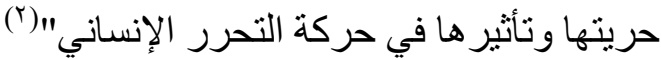

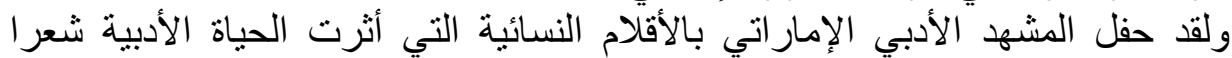

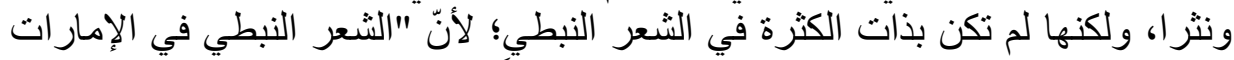

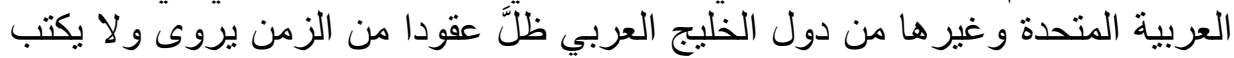

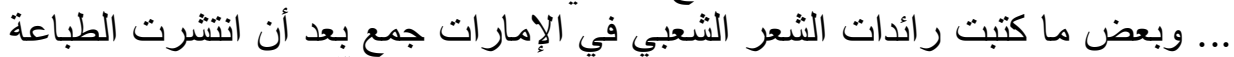

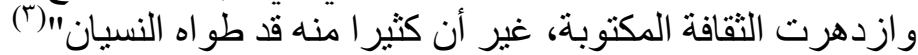

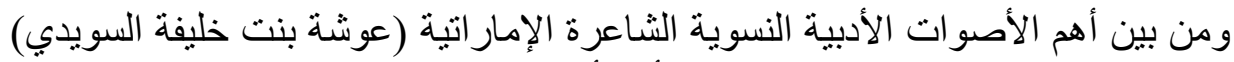

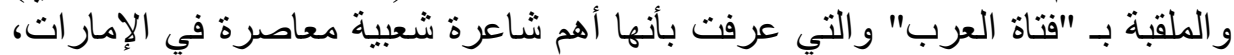

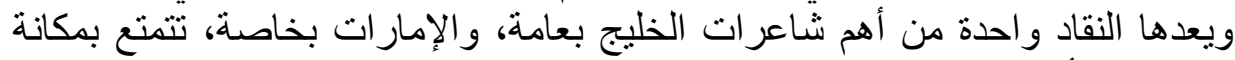

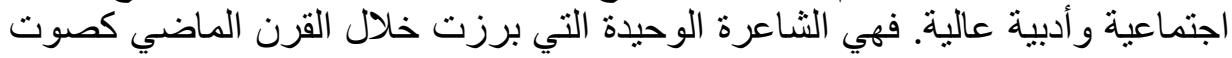

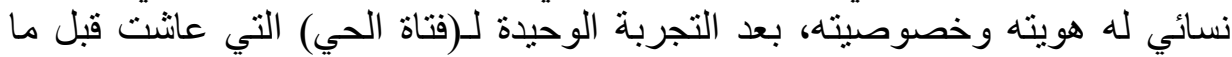

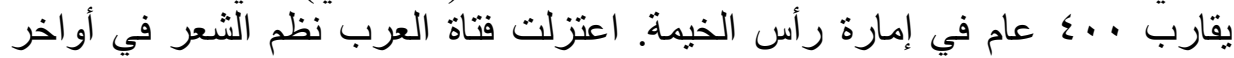

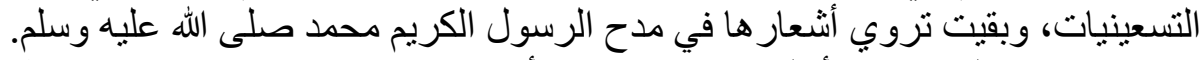

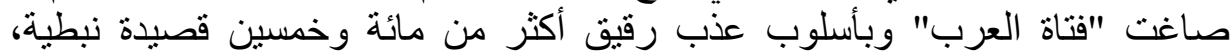

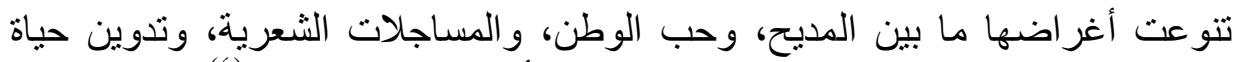

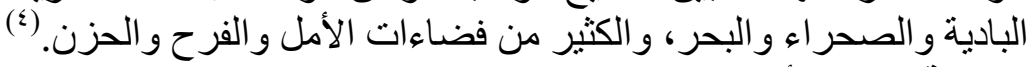

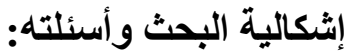

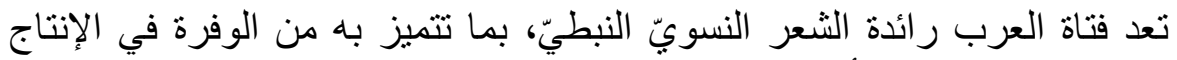

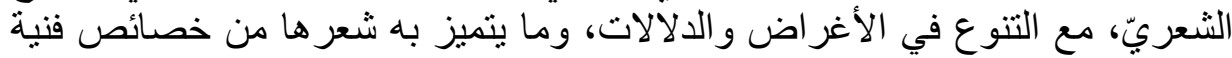

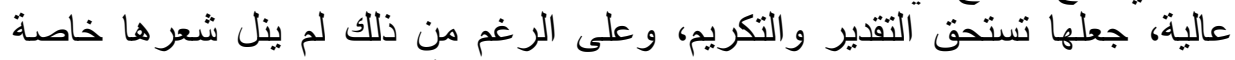

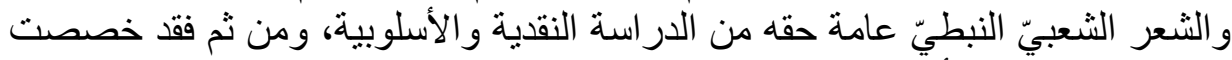

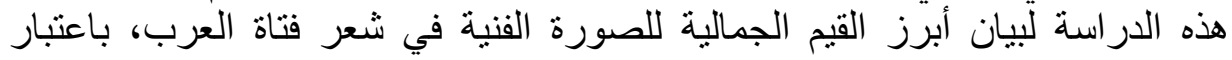

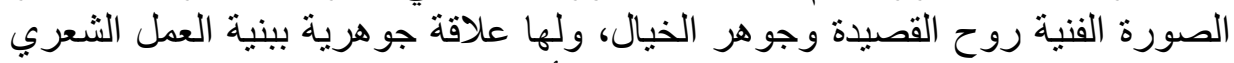
ومعاييره الجمالية. ويحاول البحث الفئ الإجابة عن الأسئلة التالية:

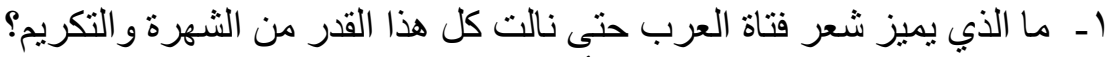

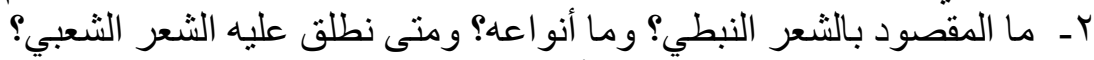

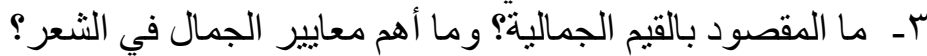

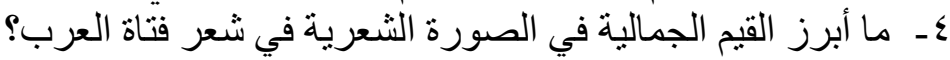

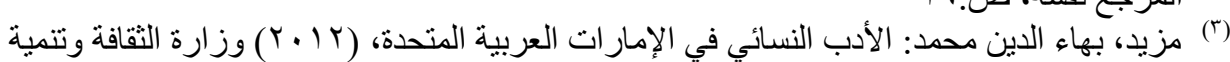

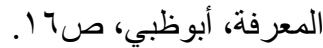
(8) بنظر ، فتاة الّرب،.. الفكر في صور الثعر (مقال سابق). 
0ـ ـ ما أدوات الصورة وما أبرز مصادر ها في شعر عوشة السويدي؟

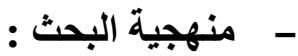

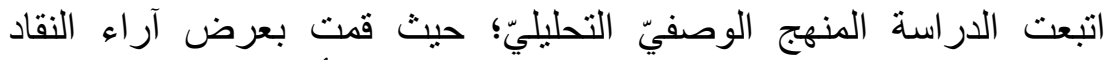

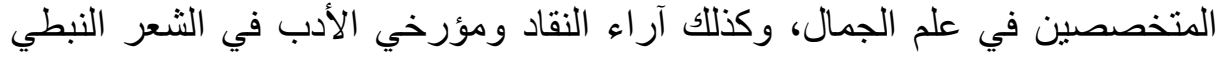

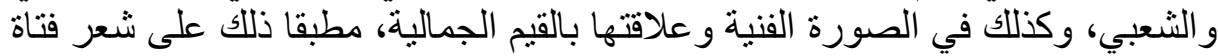

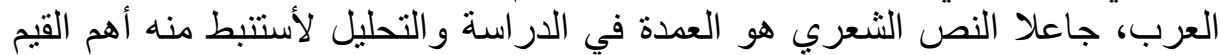
والمعايير الجمالية في الصورة النعاءئ الثعرية.

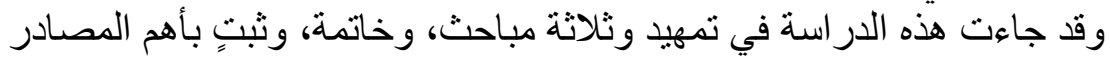

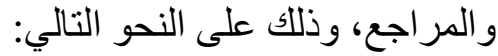

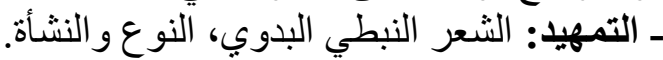

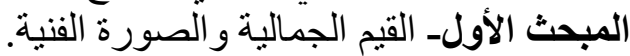

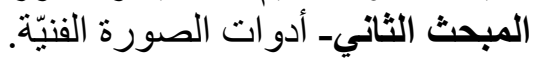

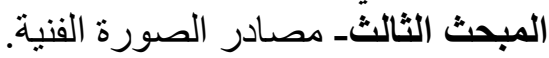

الثُعر النبطي البدوي، النوع والنشأة

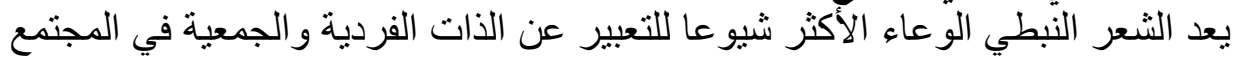

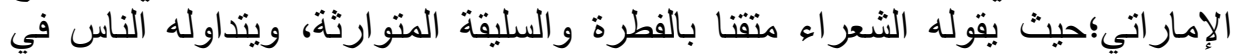

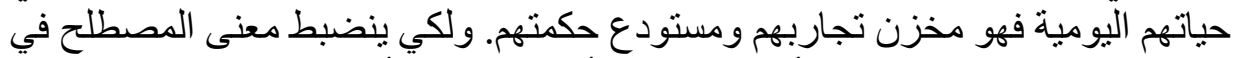

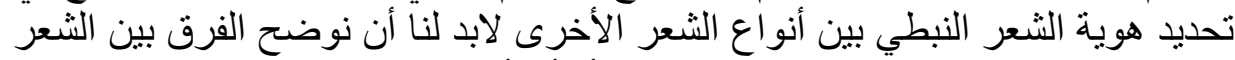

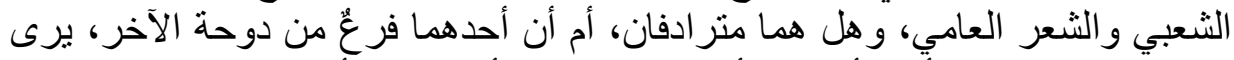

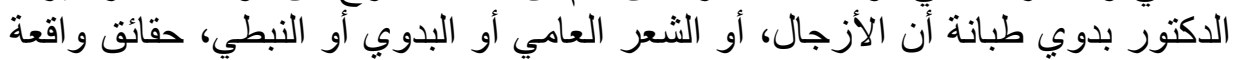

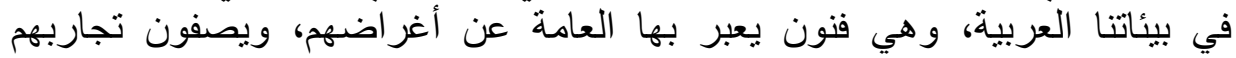

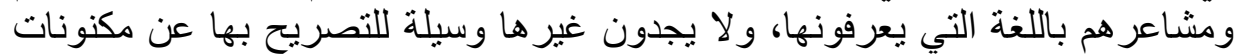

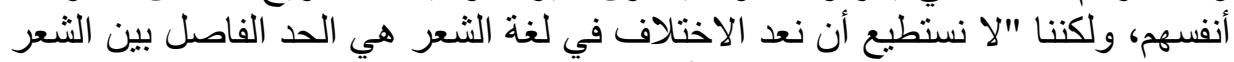

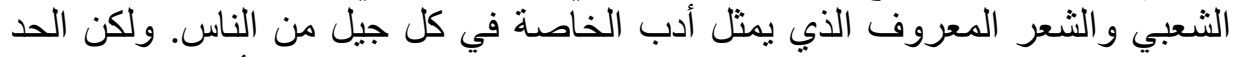

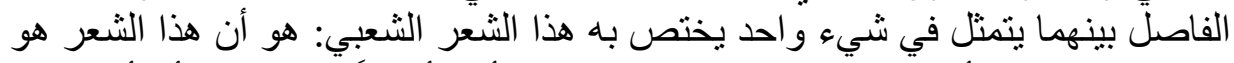

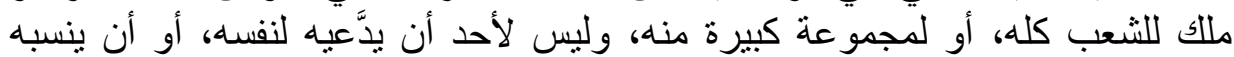

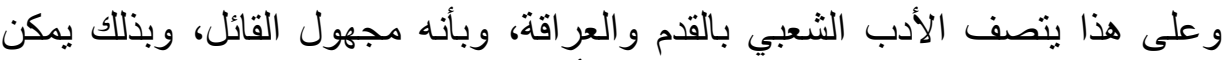

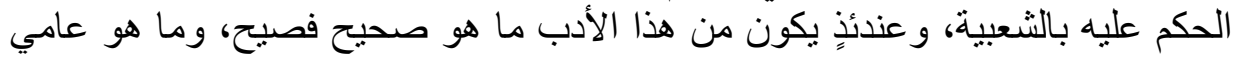




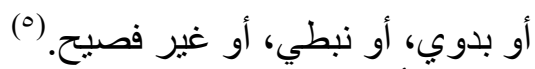

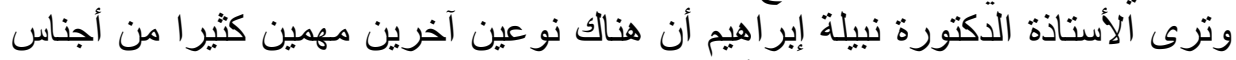

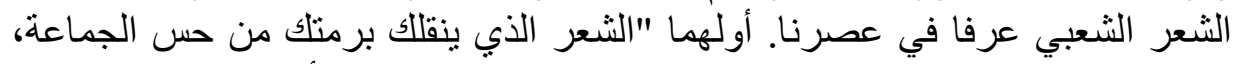

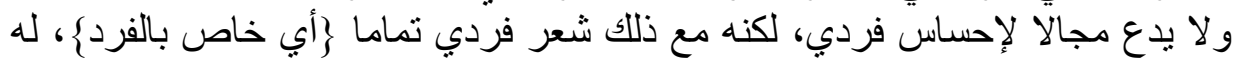

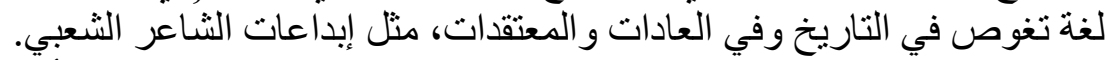

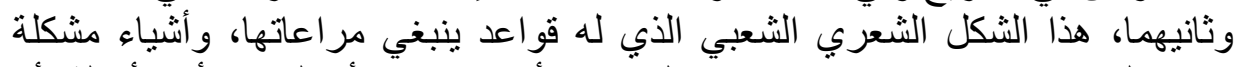

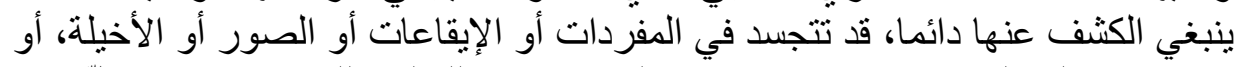

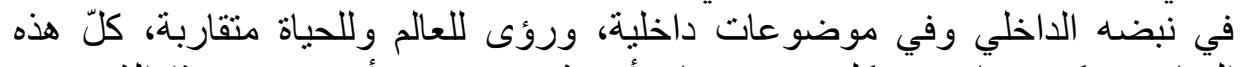

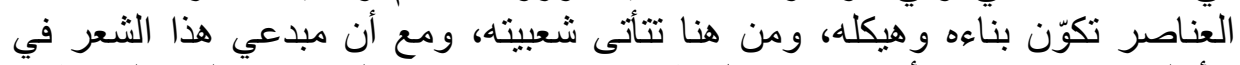

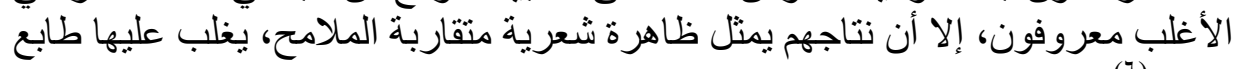

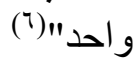

ونستنتج مما تقدّم أن العامية ليست شرطا في دخول نمط الثعر النبطي تحت مظلة

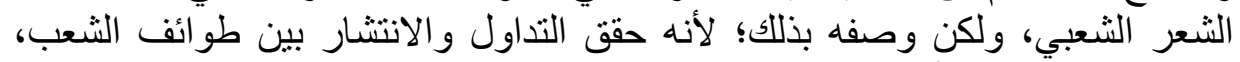

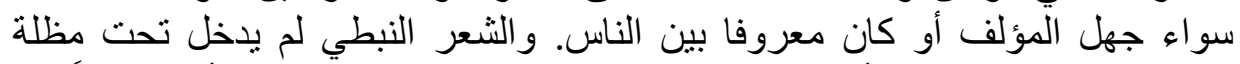

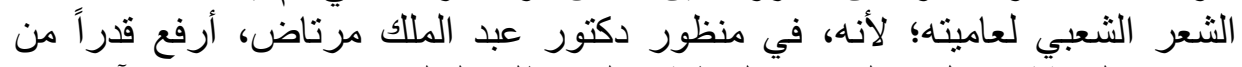

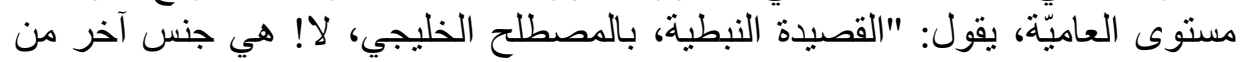

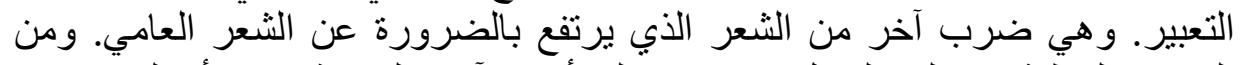

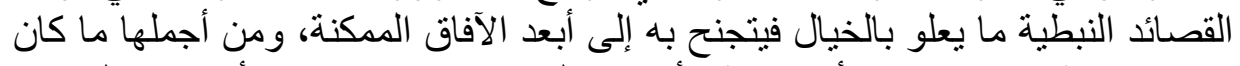

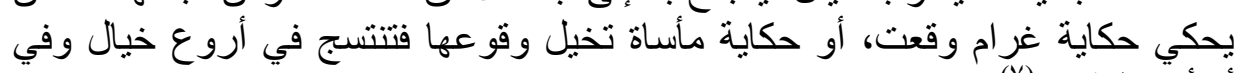

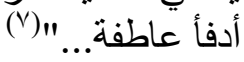

المبحث الأول- القيم الجمالية والصورة القالة القنية

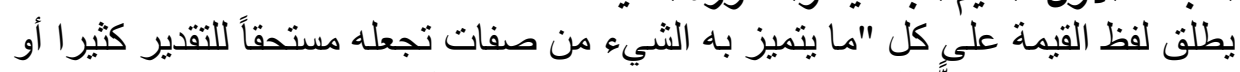

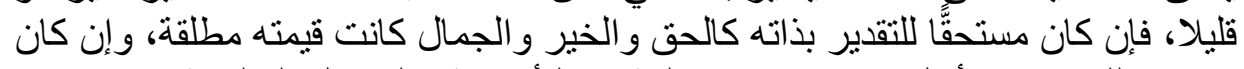

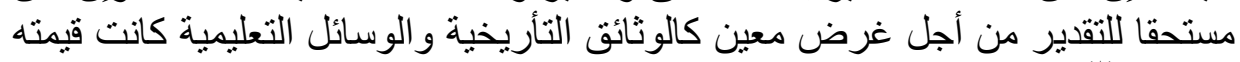

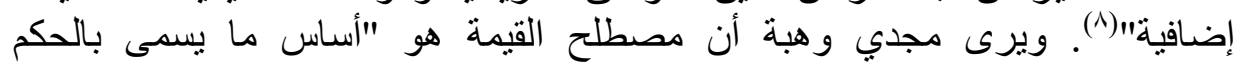

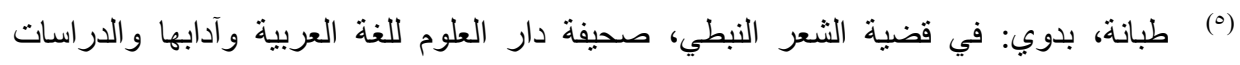

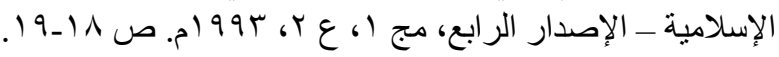

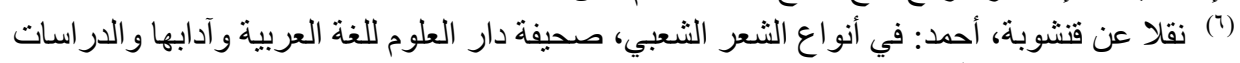

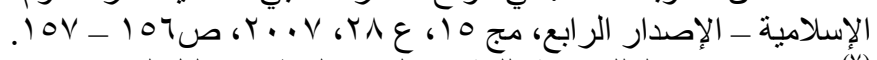

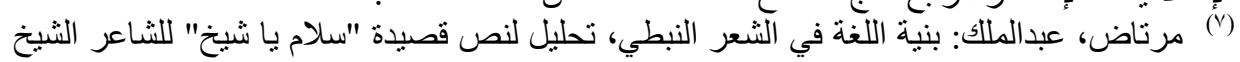

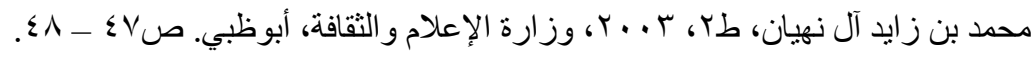

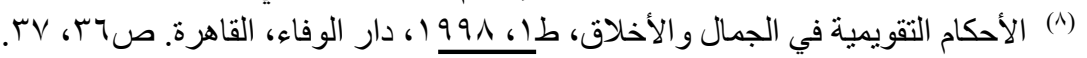


التقويمي، أي ذلك الحكم الذي يمنح المدح أو الذم لصفات براها المصدر للحكم في

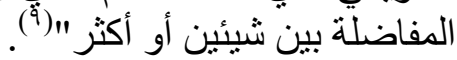

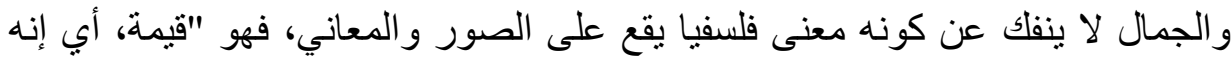

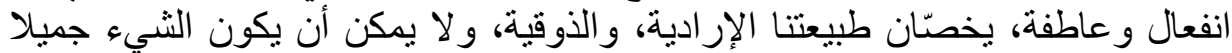

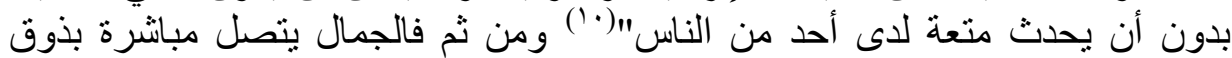

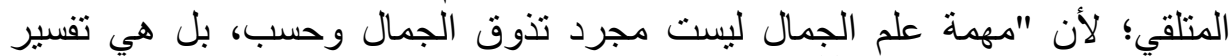

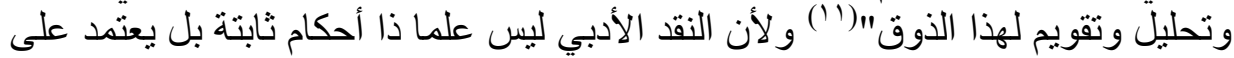

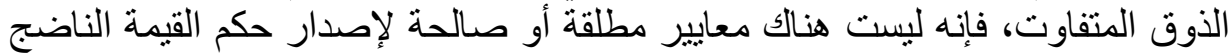

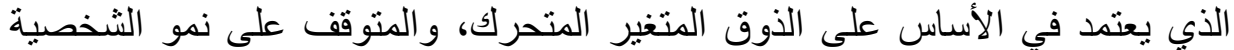

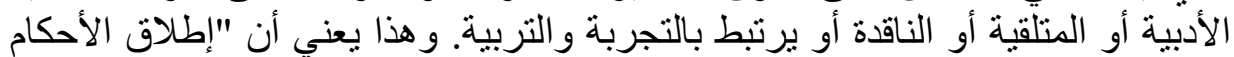

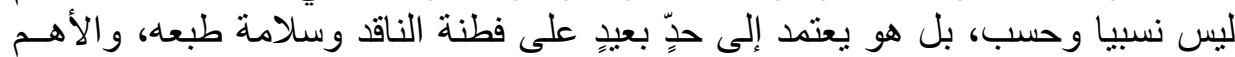

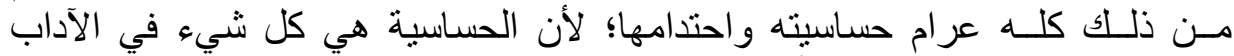

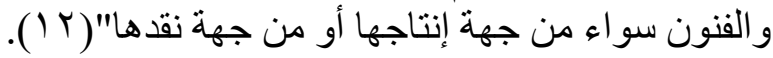
و الذهن في كل عصر "دائما يحتضن سؤال القيمة كي لا لا يتساوى النفيس

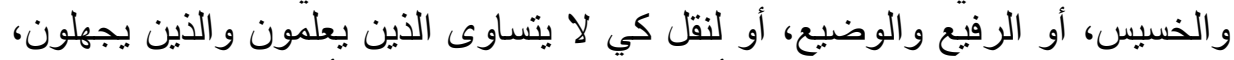

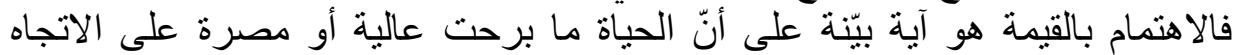

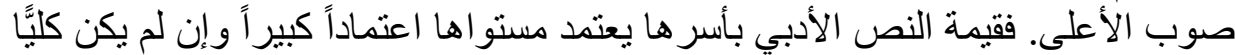

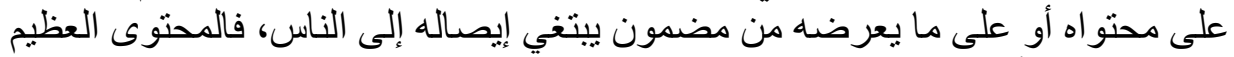

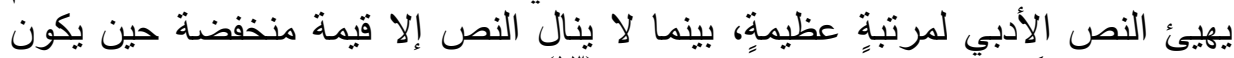

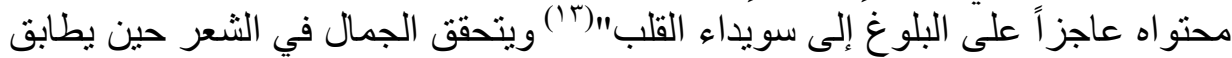

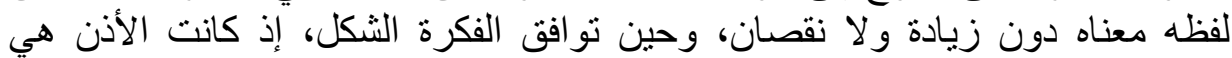

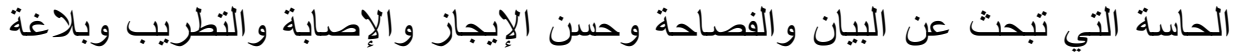

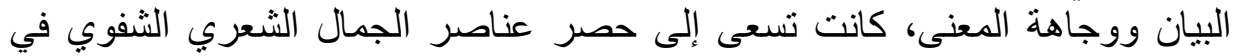
لحظة واحدة تلخصها صورة سمعية واحدة تنبئ ببر اعة الثاعر وتفوقه وخروجه عن الني

(9) وهبة، مجدي، وكامل المهندس: معجم المصطلحات العربية في اللغة والأدب، ط؟، عد9 ام، مكتبة

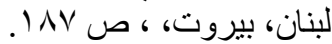

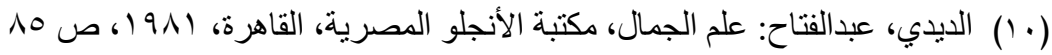

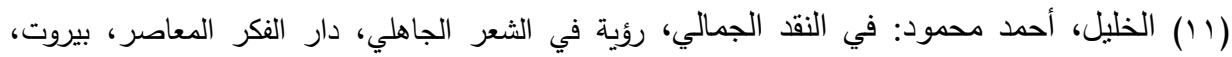


مألوف السماع وكأن مأمن الثياطين أصابه(؛ (1)

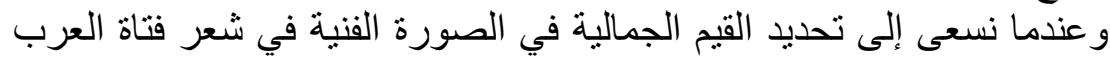

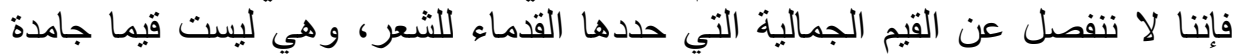

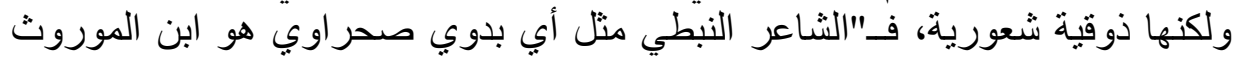

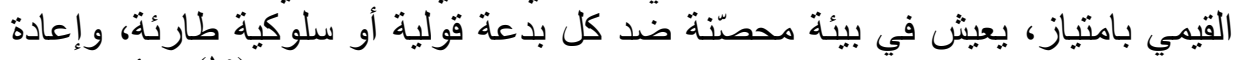

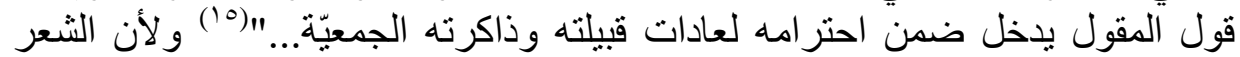

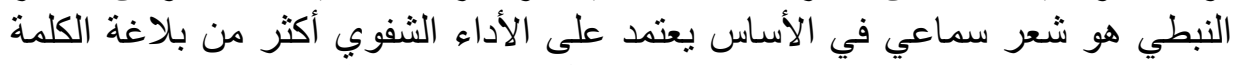

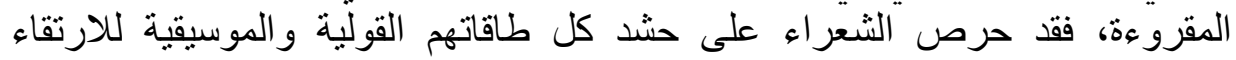

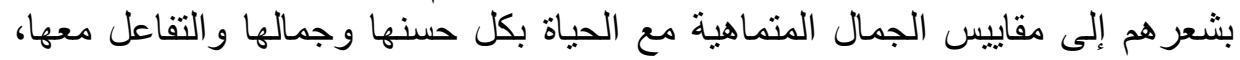

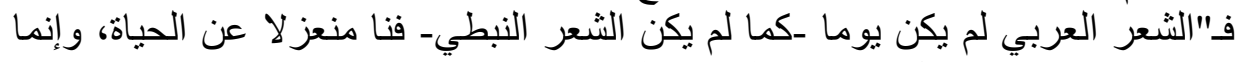

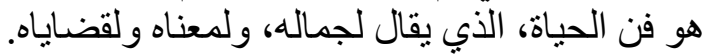

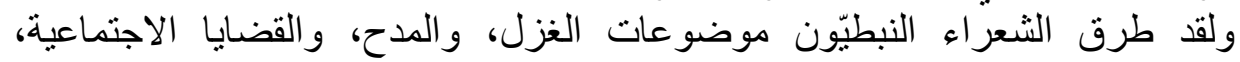

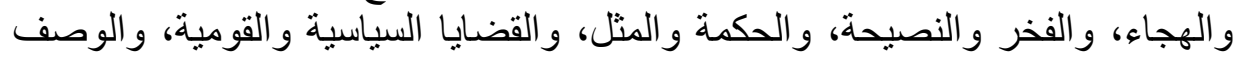

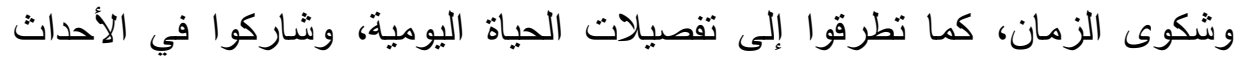

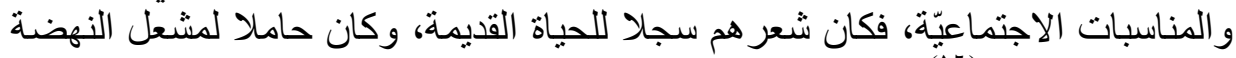

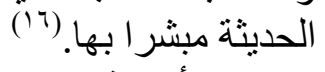

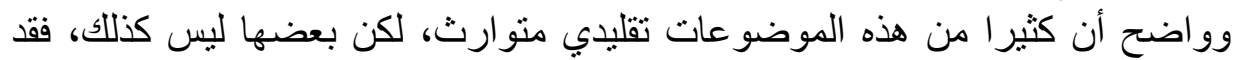

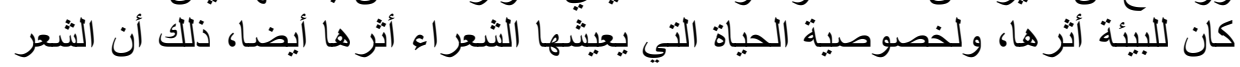

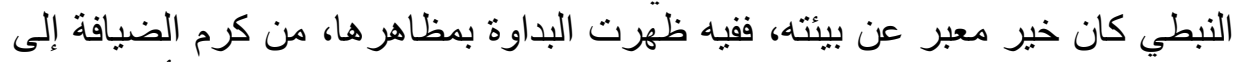

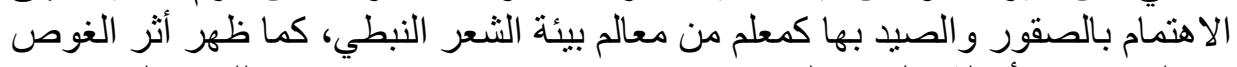
في المعاني و الأخيلة، بل إن الغوص نفسه كموضوع إنما كان صدى للفترة التي سبقت الته

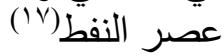

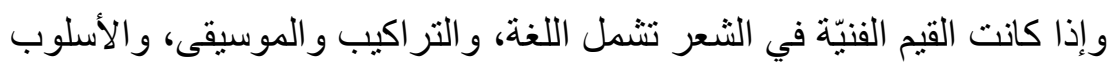

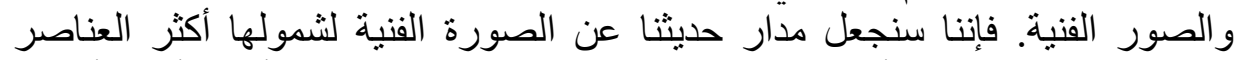
السابقة، والانطلاق إلى أعماق الصورة الفنية عند فتاة العرب لابد أن يبدأ من أعماق

(ع (1) عبّو، عبدالقادر، فلسفة الجمال في فضاء الشعرية العربية المعاصرة، طا، 10 ـr، دار رسلان للطباعة

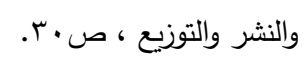

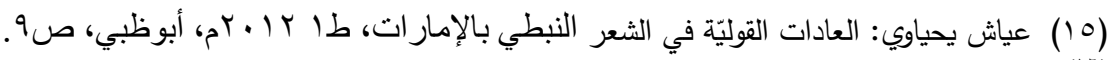

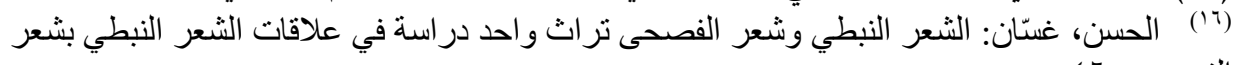


التجربة الجمالية ذاتها التي عاثتها بوجدانها سواء في بيئتها البدوية الأولى أو في البيئة

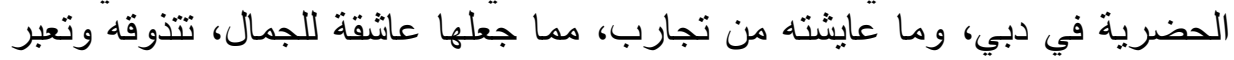

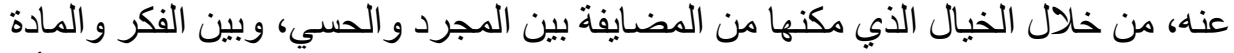

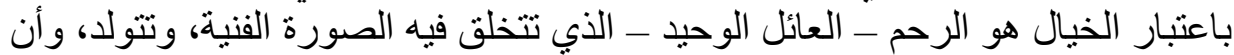

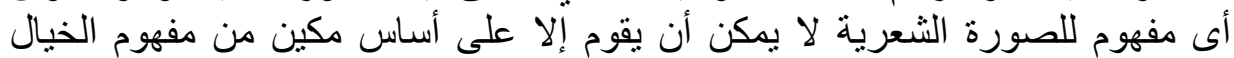

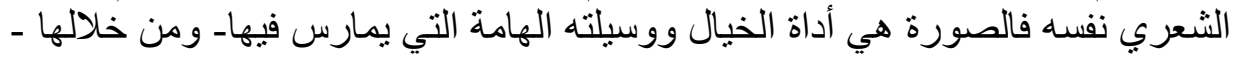

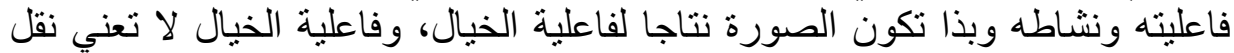

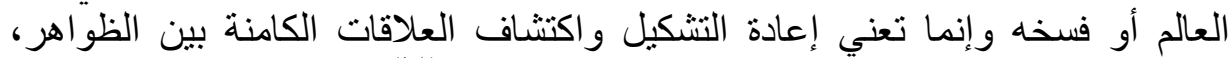

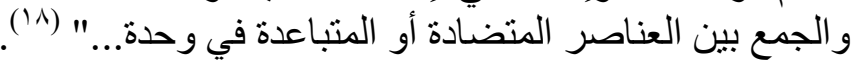

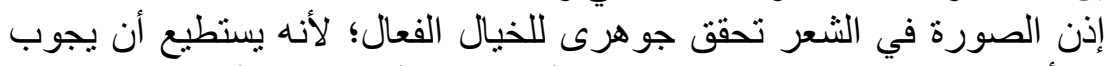

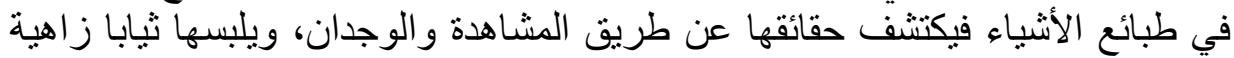

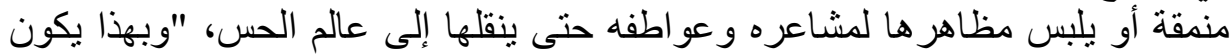

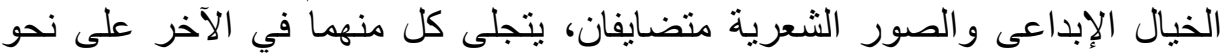

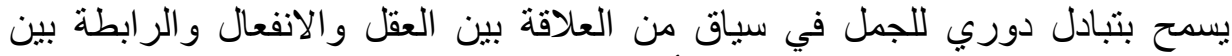

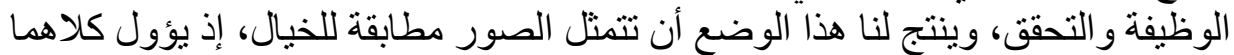

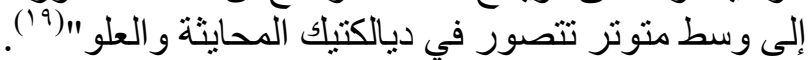

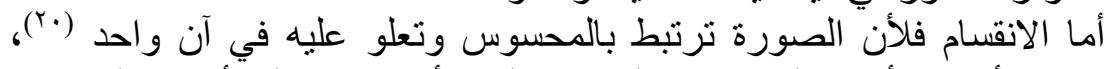

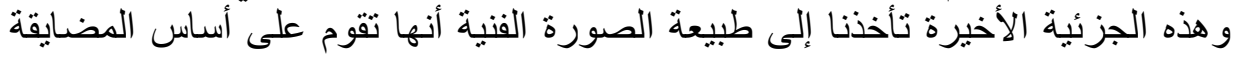

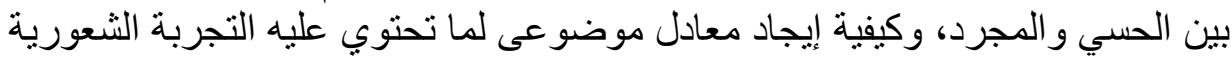

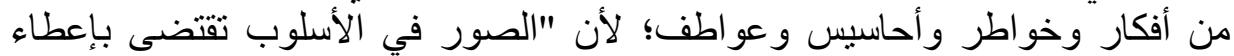

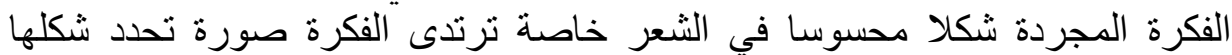

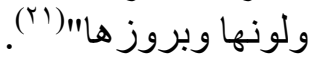

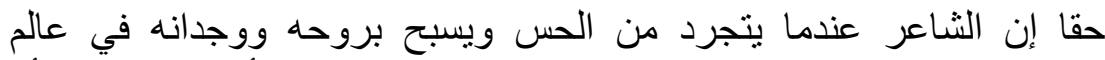

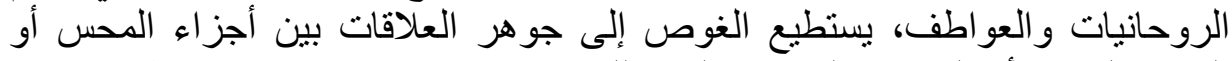

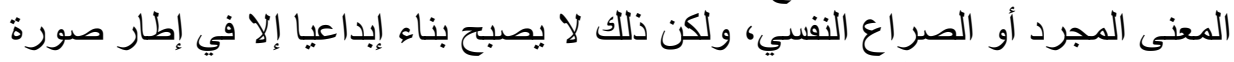
خلافية تستطيع من خلالها قياس بر العة الفة الثناعر و عبقريته.

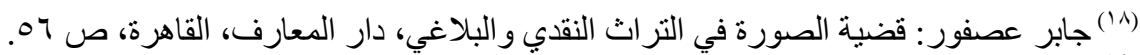

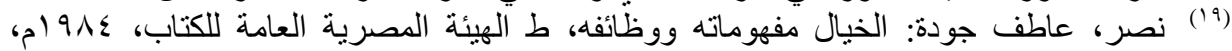

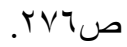

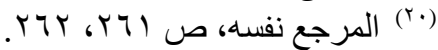

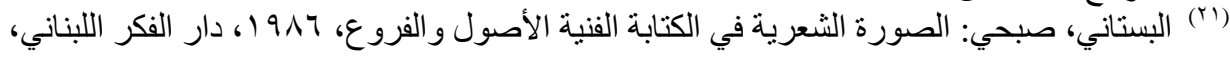




\section{المبحث الثاني- أدوات الصورة الفنية في شعر عوشة:}

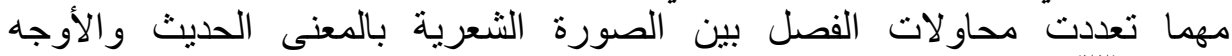

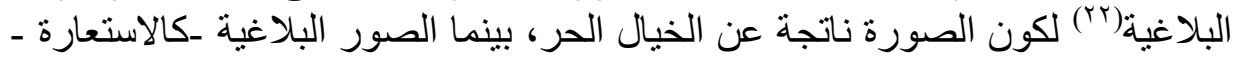

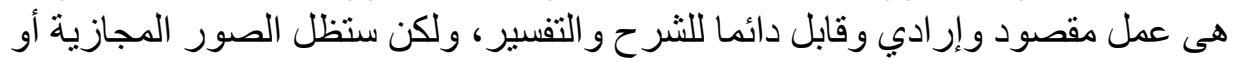

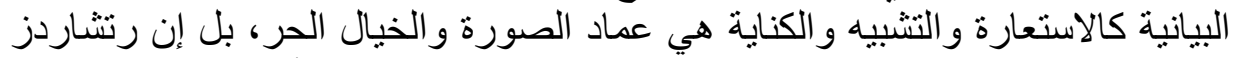

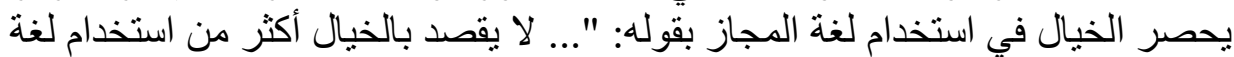

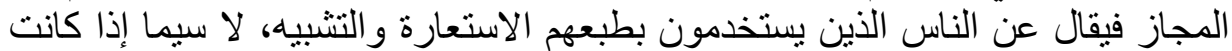

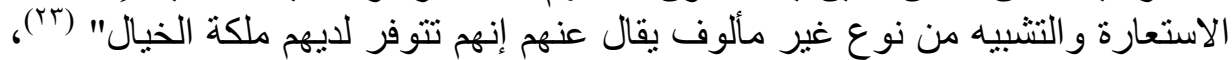

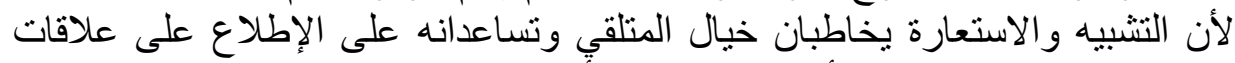

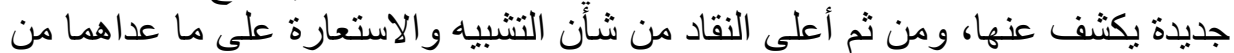

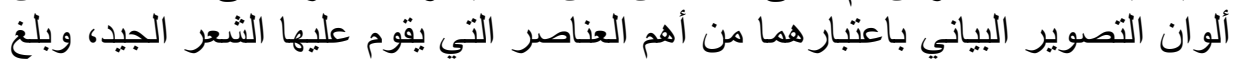

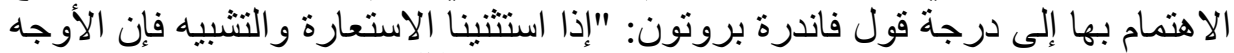

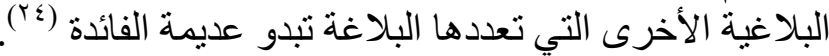

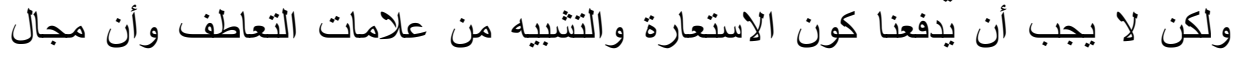

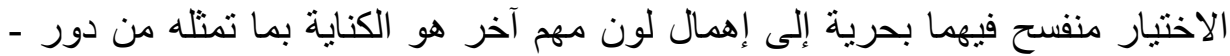

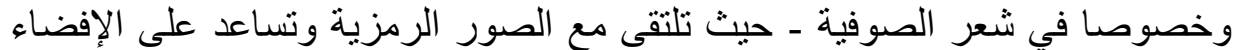

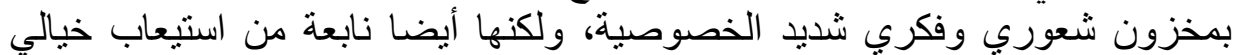

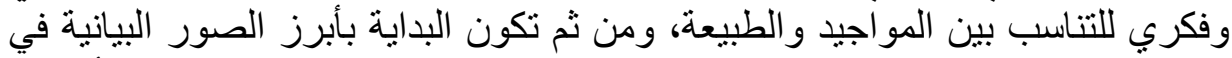

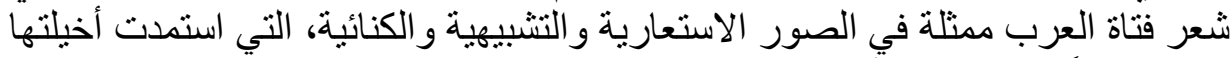

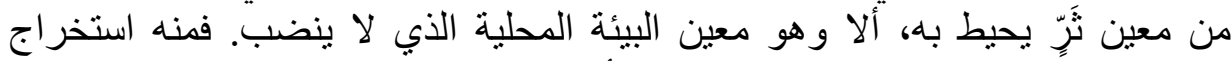

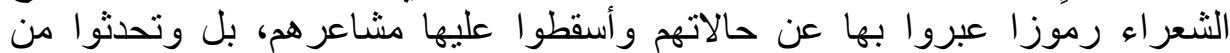

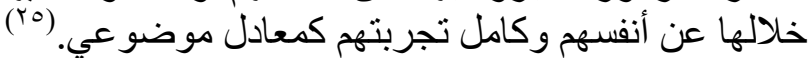

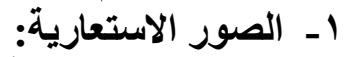

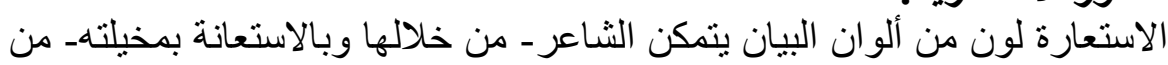

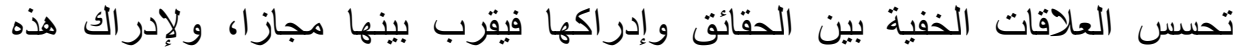
العلاقات داخل الصورة الاستعارية لابد أن "نأخذ في اعتبارنا النظرة الرمزية والإنشارية

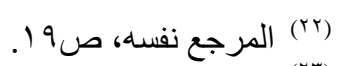

لالئ

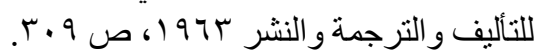

أل (ro( الحسن، غسّان حسن أحمد: الثعر النبطي في منطقة الخليج و الجزيرة العربية در اسة علمية، القسم 
للغة. و الاستعارة الجيدة أو الناجحة هي التي تحقق ضربا من المعاني الكثفية وتثرى

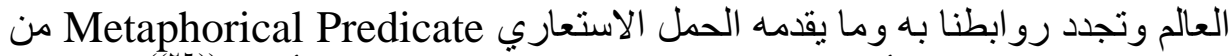

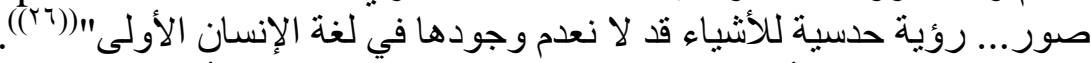

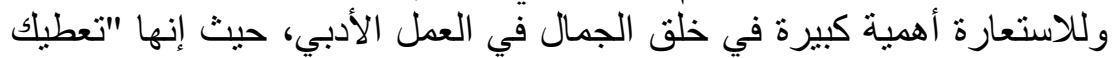

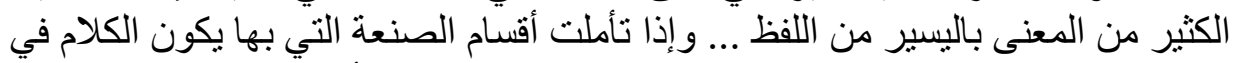

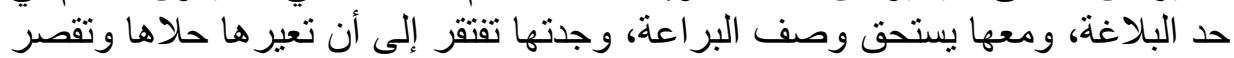

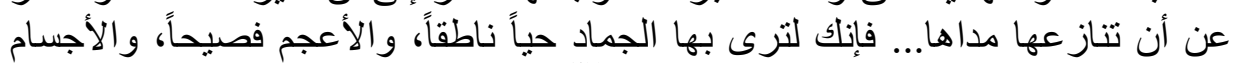

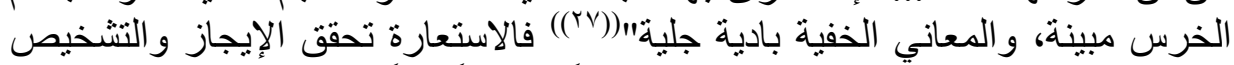

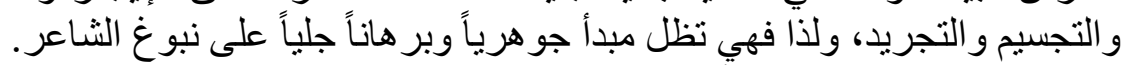

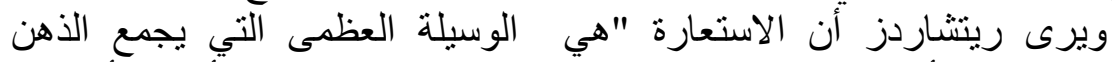

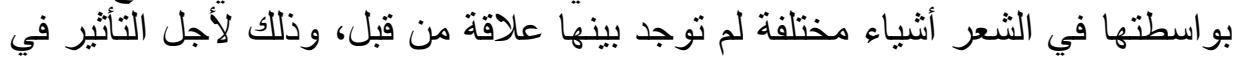

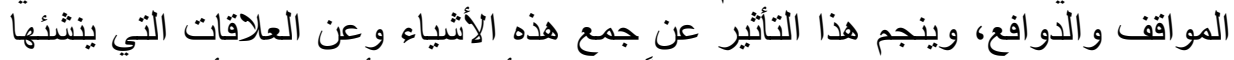

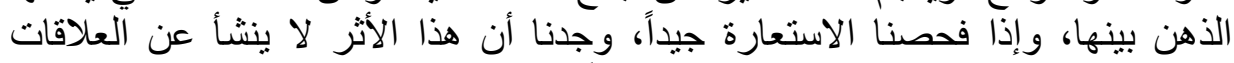

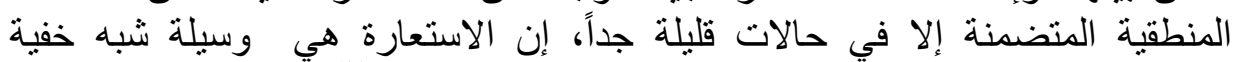

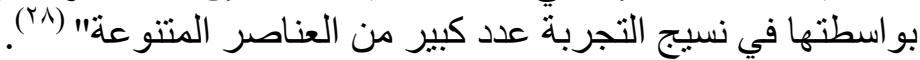

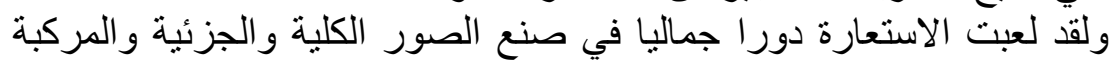

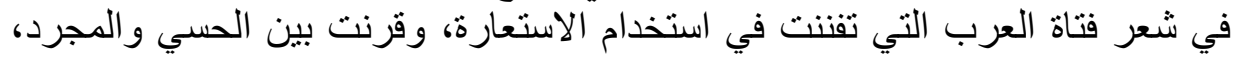
و ألتشخيص و التجسيم، تقول:

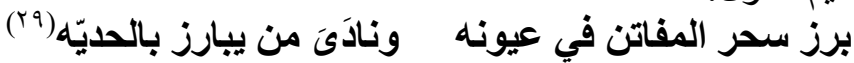

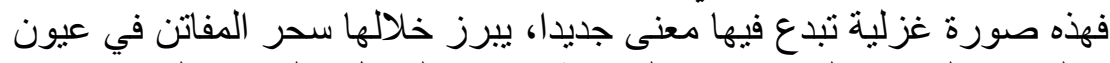

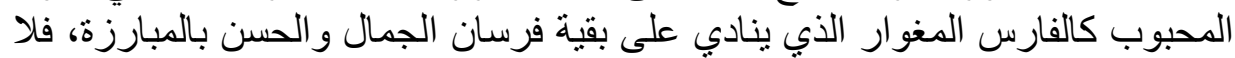

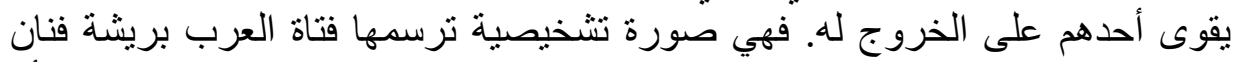

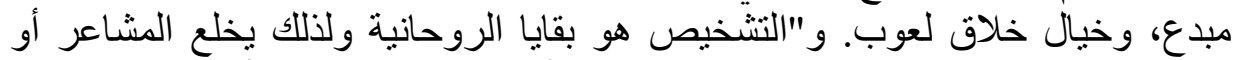

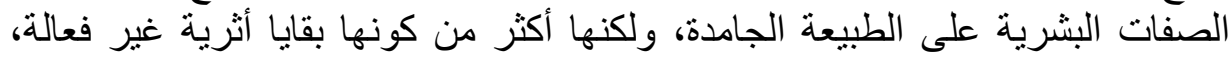

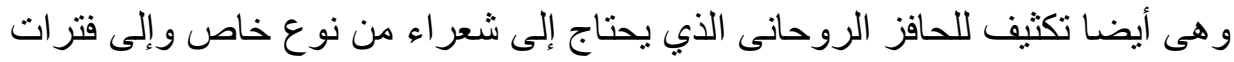

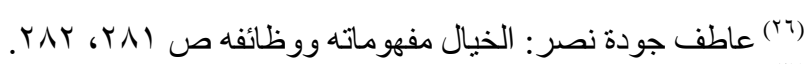

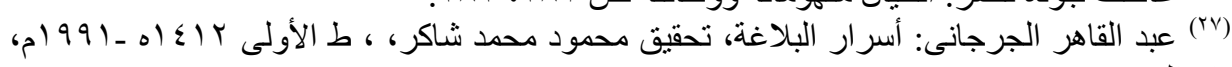

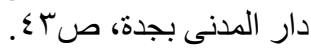

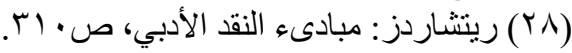

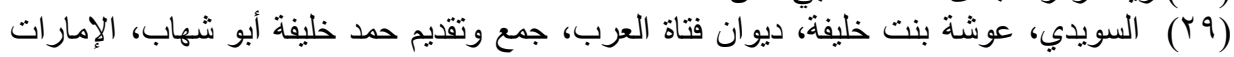

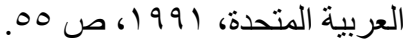




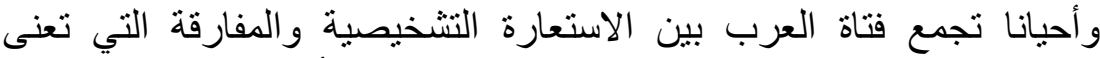

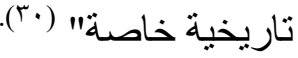

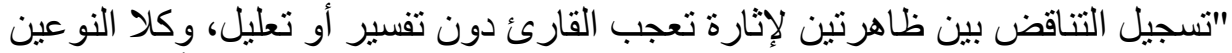

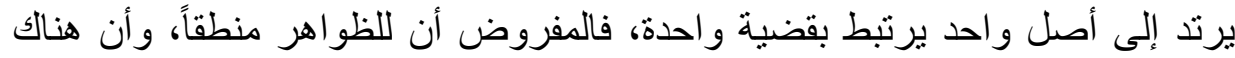

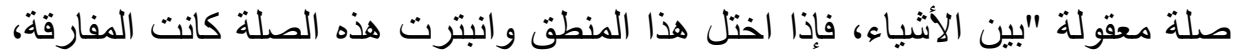

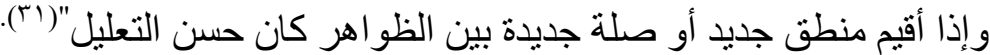

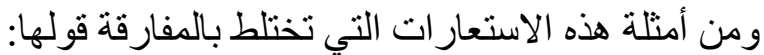

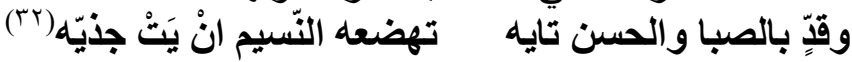

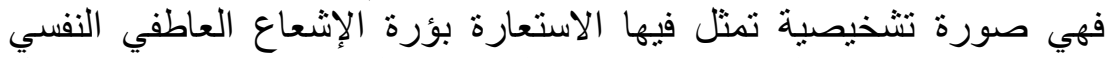

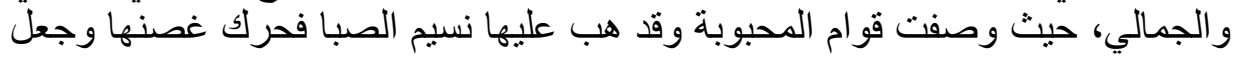

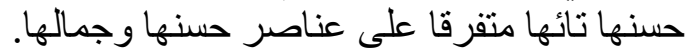
وفي صورة استعارية تشخيصية تقول في ردها على الثاعر عمير بن راشد آل عفيشه

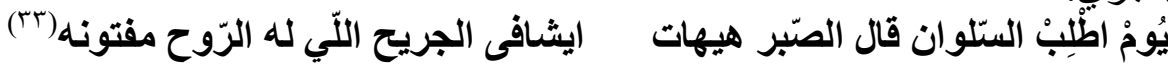

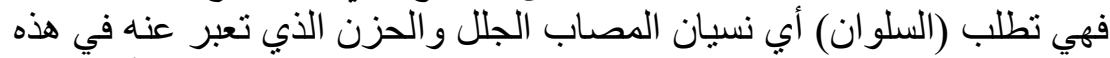

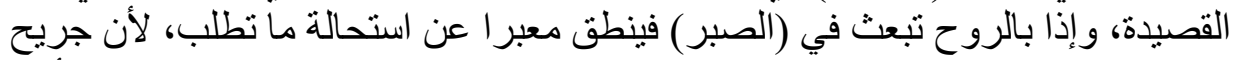

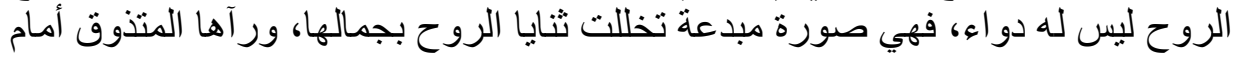

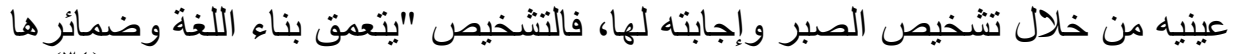

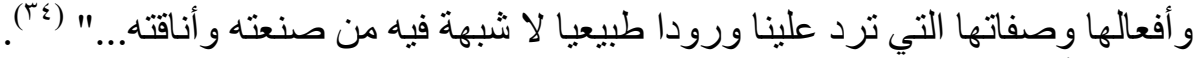

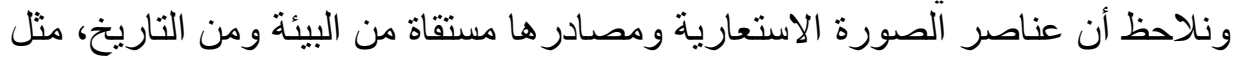

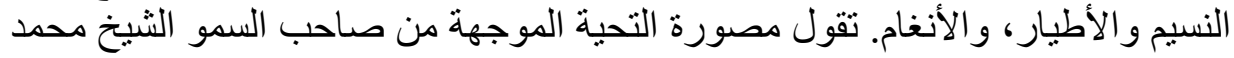

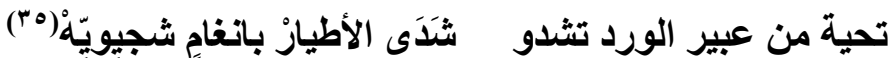
بن راشد:

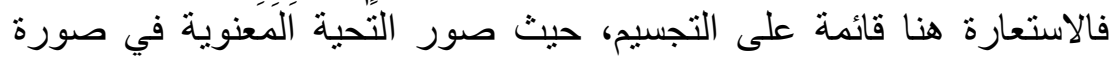
(·•) س. دى. لويس: الصورة الثعرية، ت أحمد نصيف الجنابي، وأخرين، منشورات وزارة الثقافة

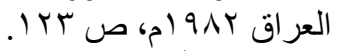
(آ⿱ عبد العزيز الأهو اني: ابن سناء الملك ومشكلة العقم والابتكار ، ط القاهرة (من دون تاريخ)، ص

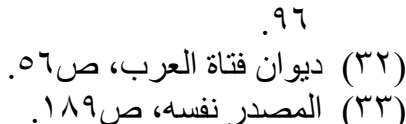

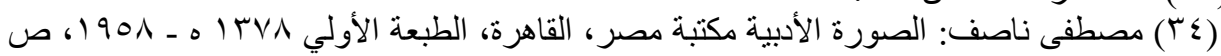


حسية تجسيمية بعبير الورود الحسي الذي يفوح في بستان تتغنى فيه الأطيار بأنغام

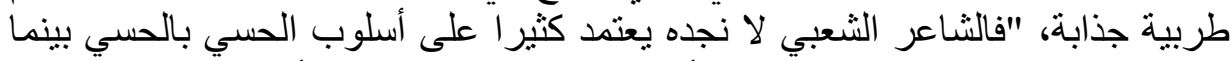

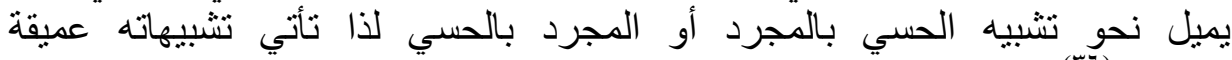

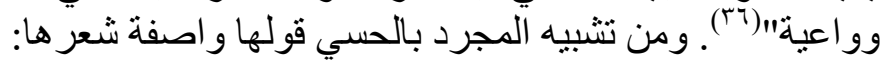

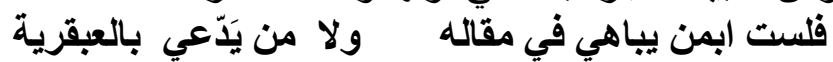

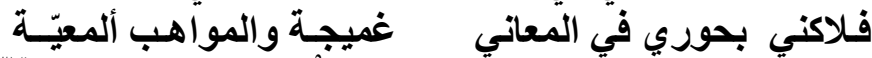

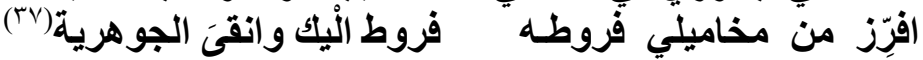

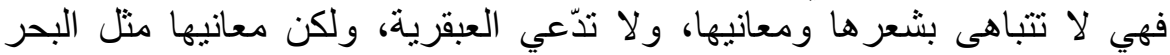

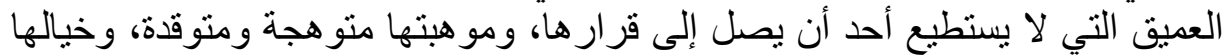

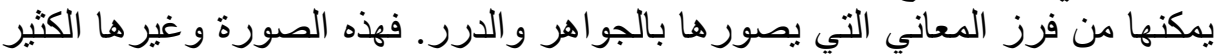

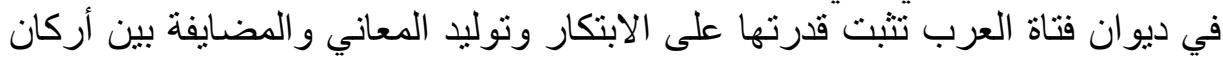

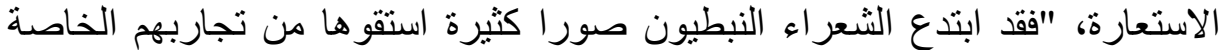

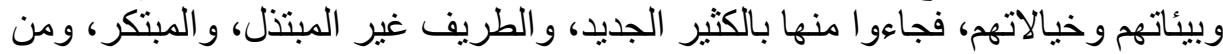

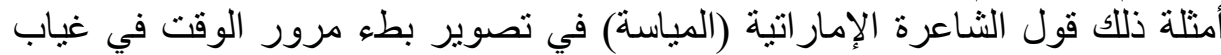

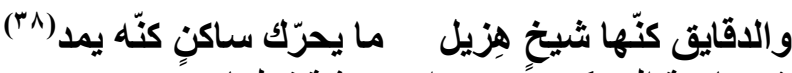

الحبيب:

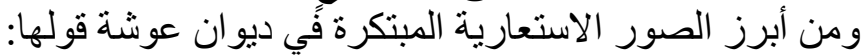

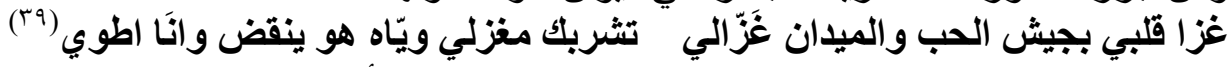

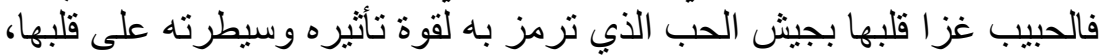

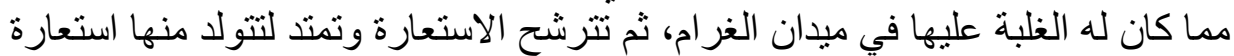

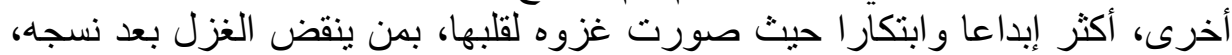

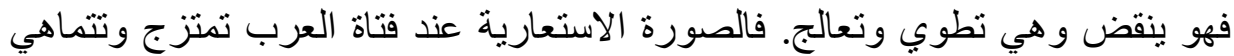

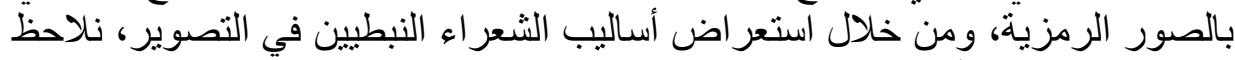

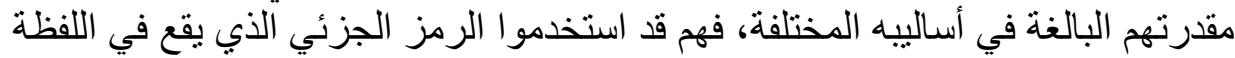

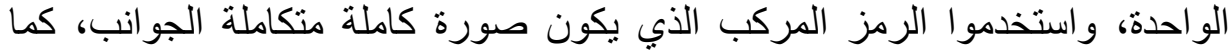
استخدموا الرمز الكلي أو المعادل، الذي يستغرق القصيدة بكاملها. ويعبر الثناعر فيه عن التيه

(T) الخروصي، حمد: الصورة الفنبّة في الثعر الثعبي، جريدة الوطن، مسقط، الأحد 9 من سبتمبر،

(†^) الحسن، غسّان حسن أحمد: الثعر النبطي في منطقة الخليج و الجزيرة العربية دراسة علمية، القسم 


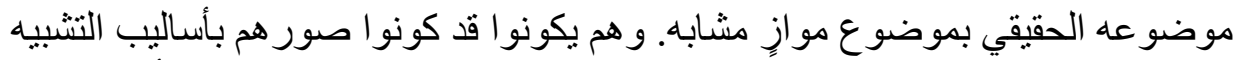

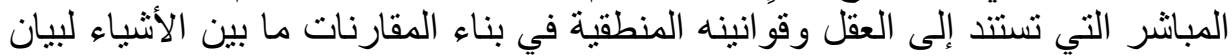

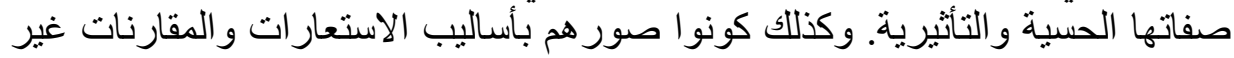

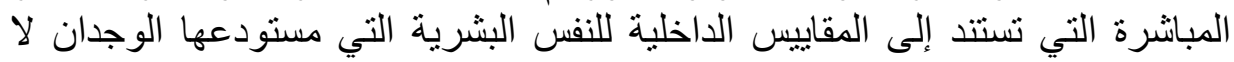

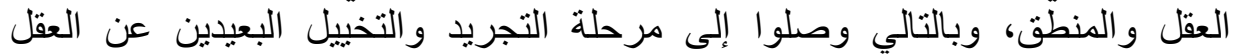

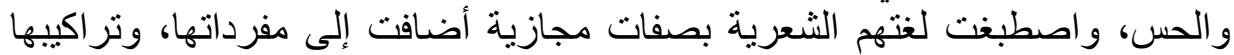

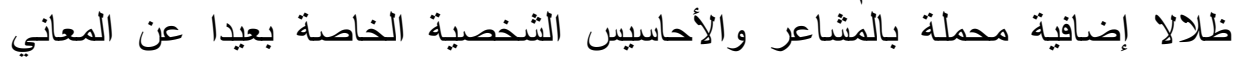

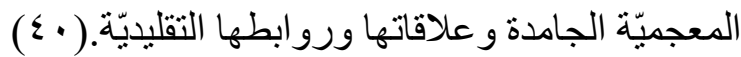

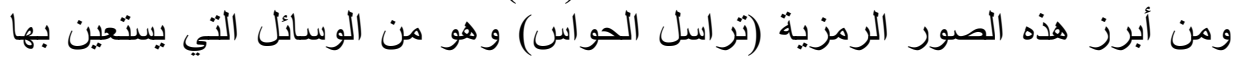

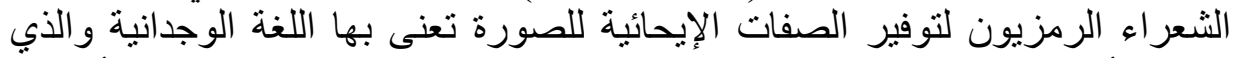

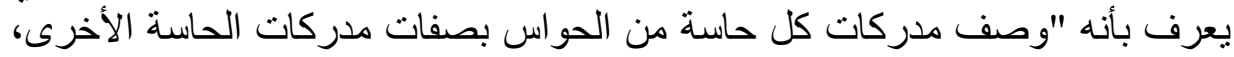

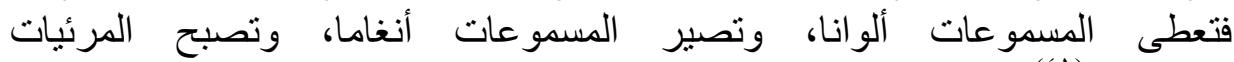

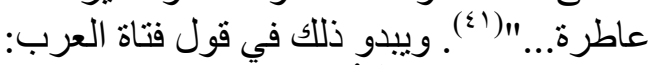

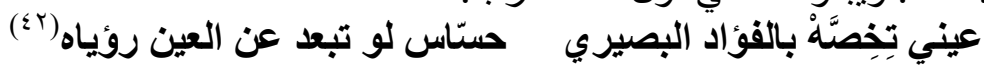

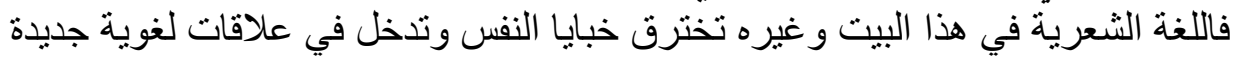

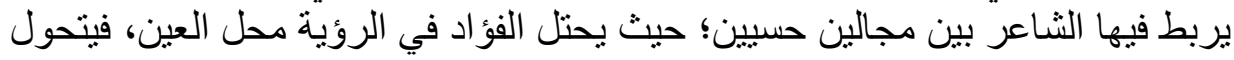

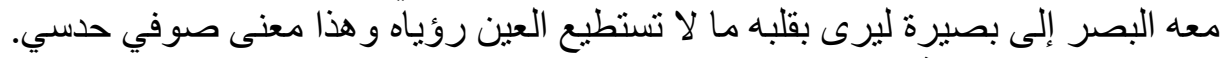

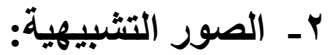

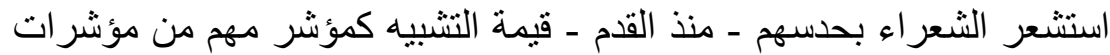

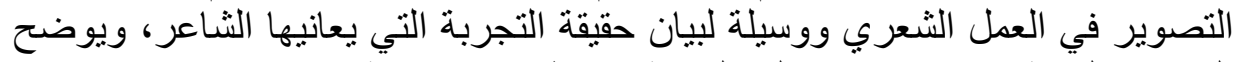

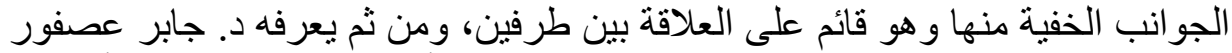

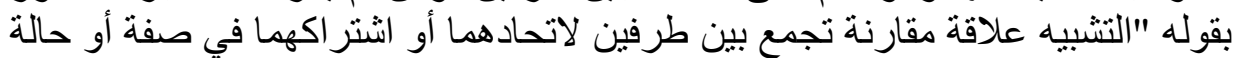

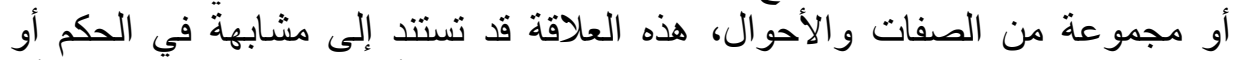

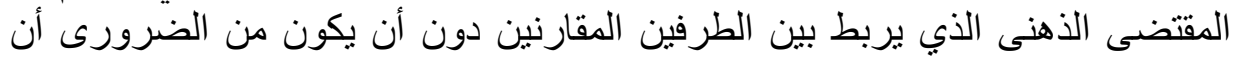

(.) الحسن، غسّان: الثعر النبطي وشعر الفصحى تراث واحد دراسة في علاقات الشعر النبطي بشعر

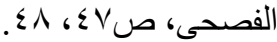

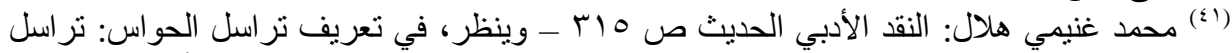

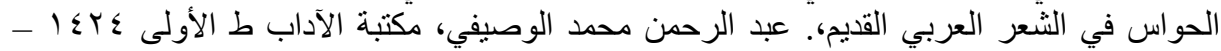

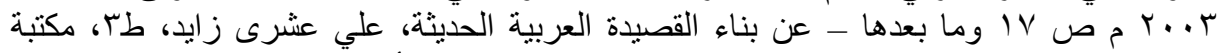

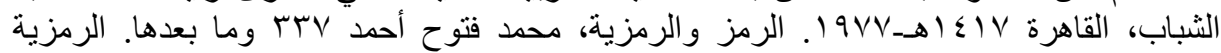

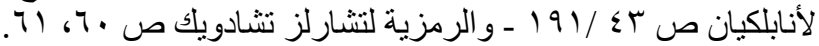


يثترك الطرفان في الهيئة المادية أو كثير من الصفات المحسوسة" ("آ؟).

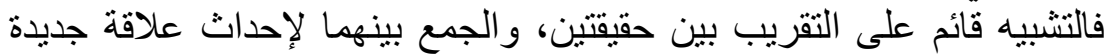

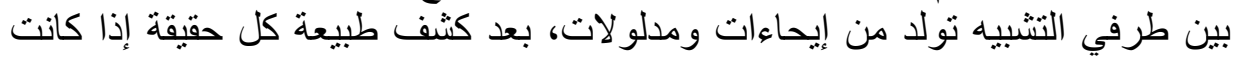

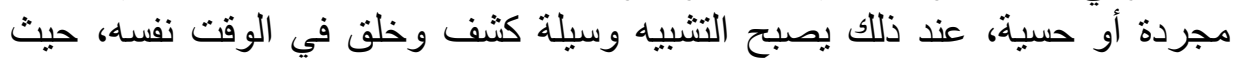

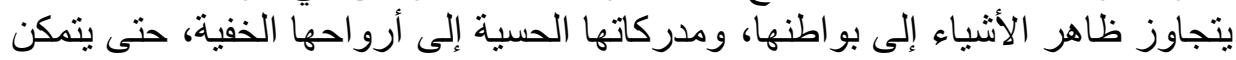

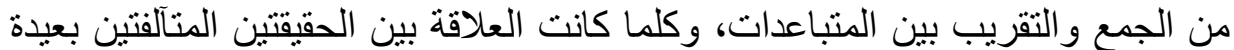

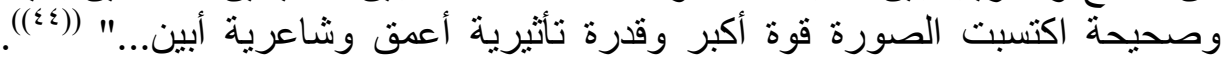

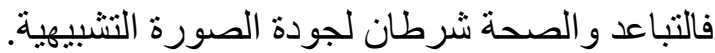

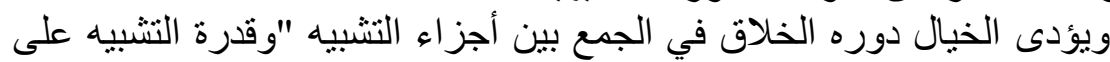

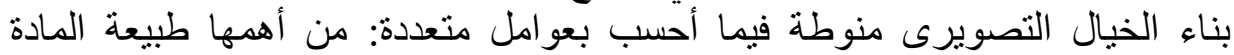

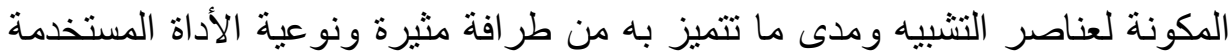

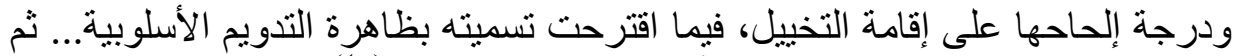

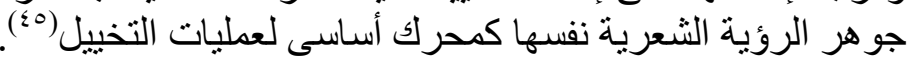

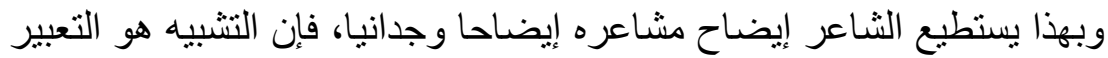

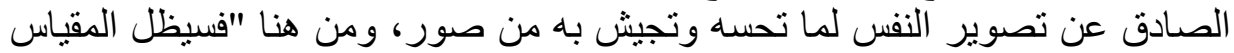

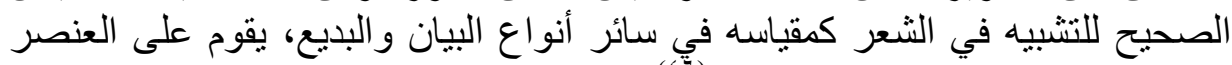

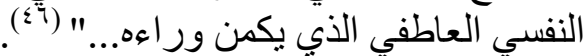

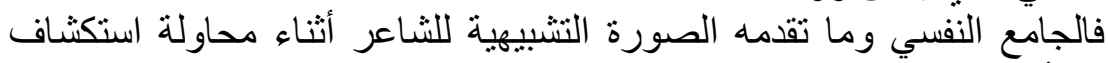

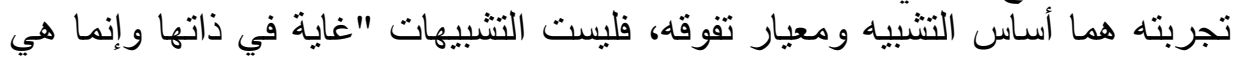

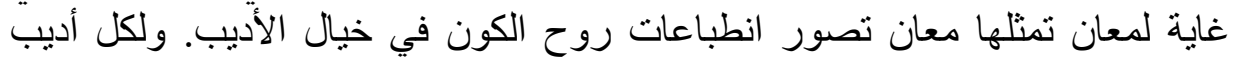

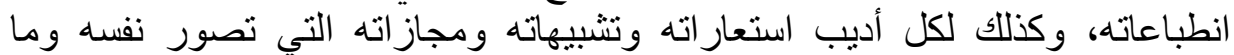

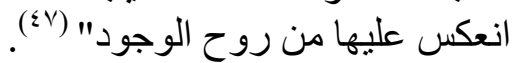

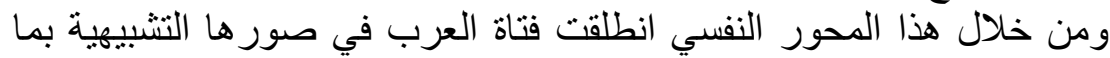

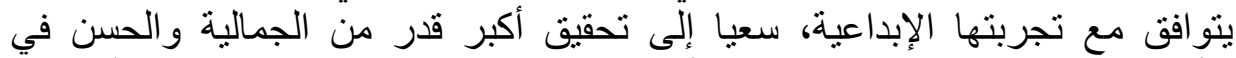
الأسلوب، "فالتثبيه يقوم بوظيفة ذات أهمية في تحقيق الجمالية في الفن، وذلك أنه ينقل

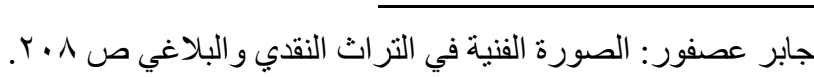

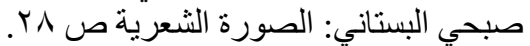

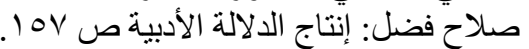

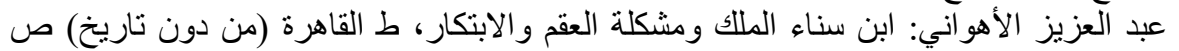

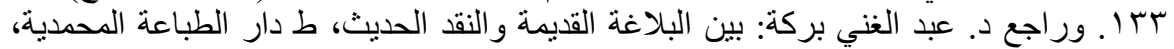

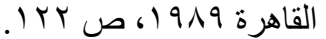
شوقي ضيف: في النقد الأدبي، ط السادسة، دار المعارف القاهرة، ص س VI التصرف. 
الصورة الأصلية إلى صورة متخيلة تكسو الشعر جمالا وتكسبه مَنْقبة وترفع من قدره،

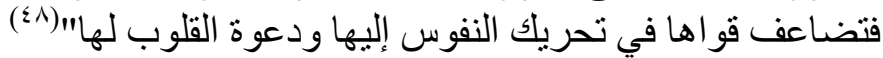

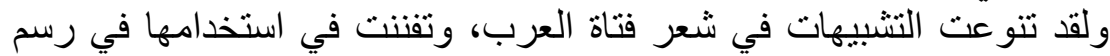

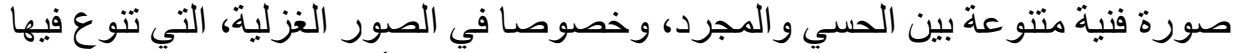

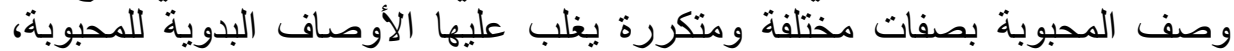

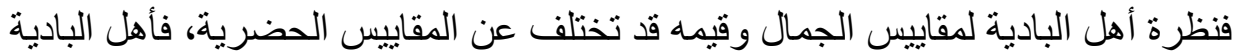

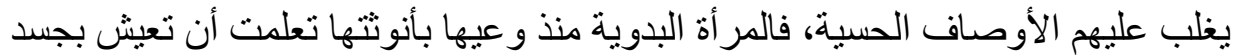

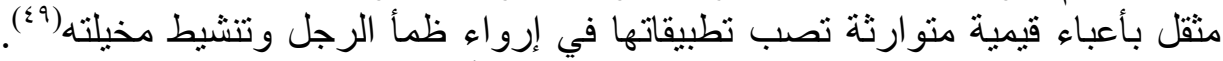

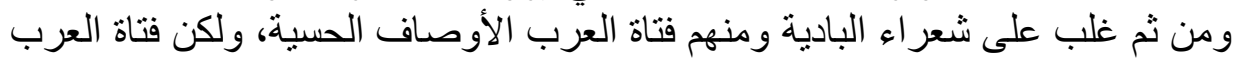

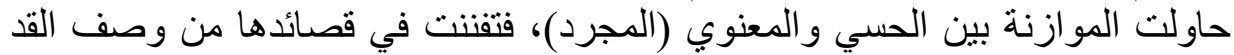

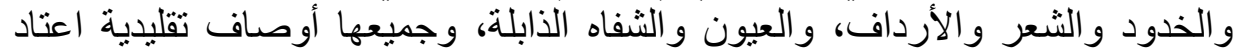

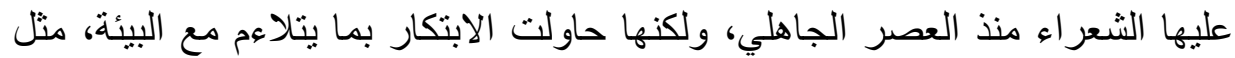

تشبيه قوام المحبوبة بغصن الموز الموز في صور متكررة:

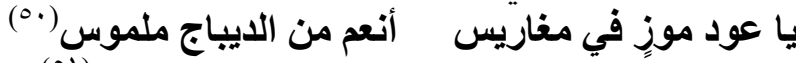

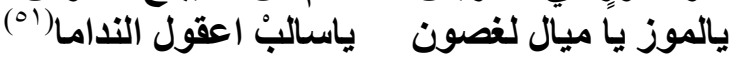

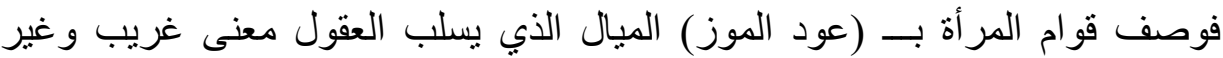

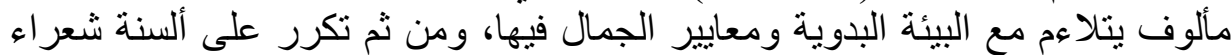

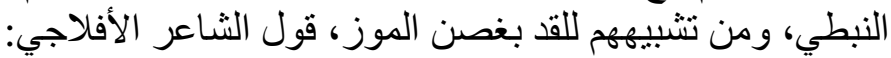

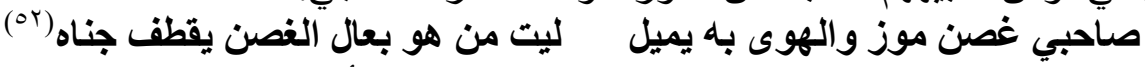

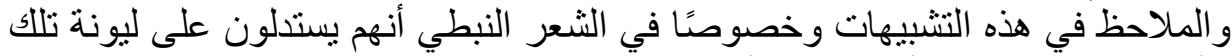

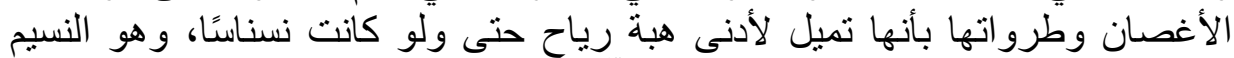

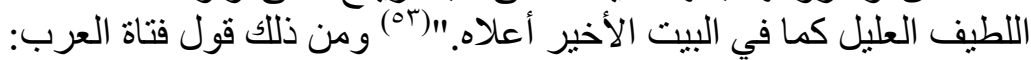

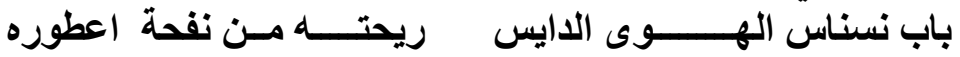

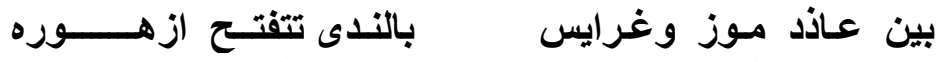

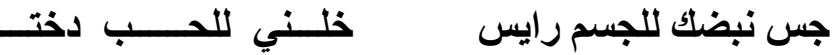

(^^) القداح، محمد مرشد قسيم، القيم الجمالية في شعر ابن المعتز، رسالة ماجستير، كلية الآداب، جامعة

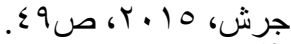

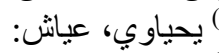

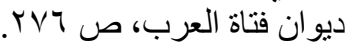

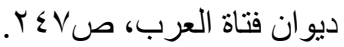

القاضي، عبد العزيز، سياحة في بيت بيت عود ريحان، صحيفة الجزيرة السعودية،

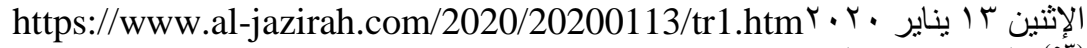
(القاضي، عبد العزيز ، سياحة في بيت عود ريحان، مرجع سابق. 


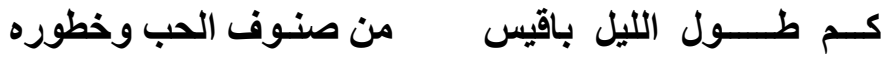

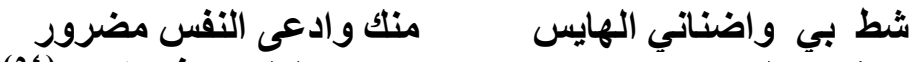

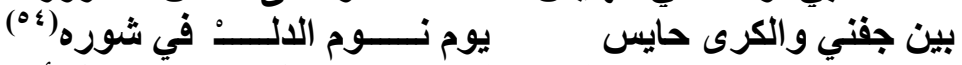

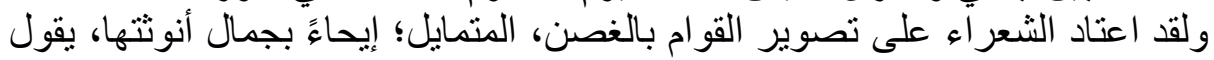

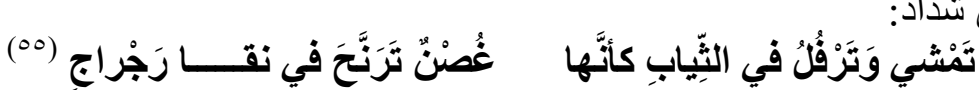

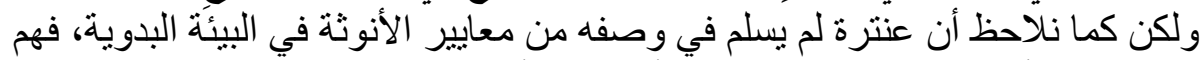

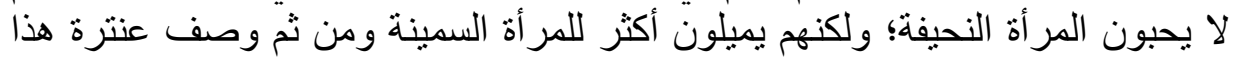

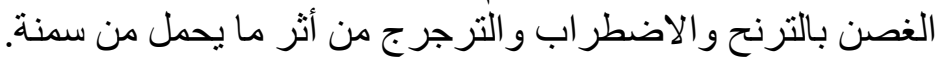

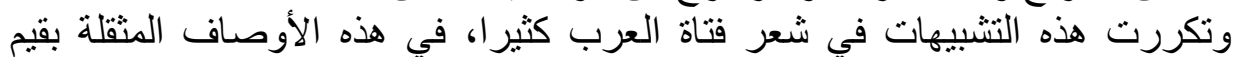

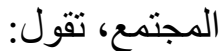

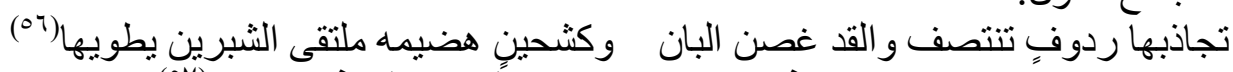

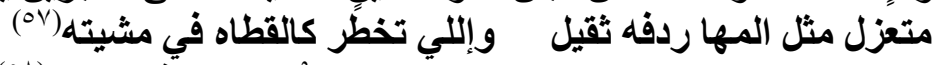

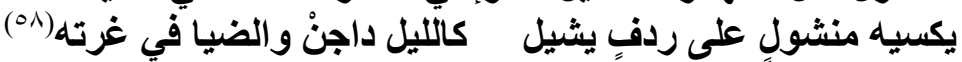

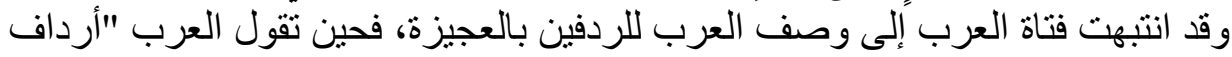

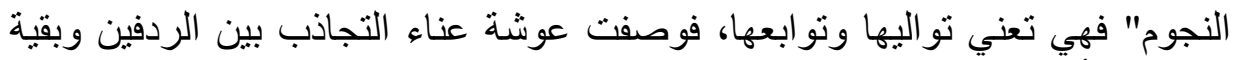

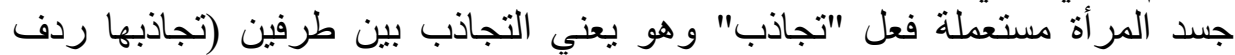

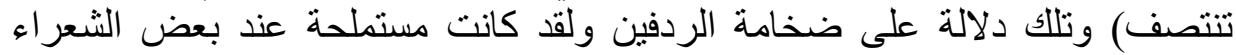

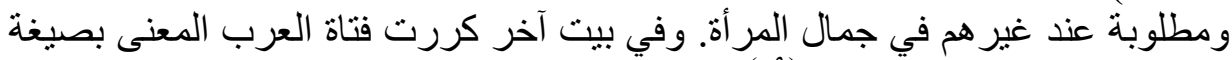

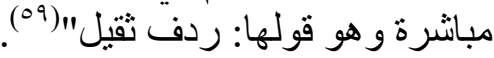

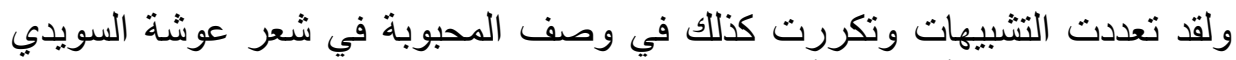

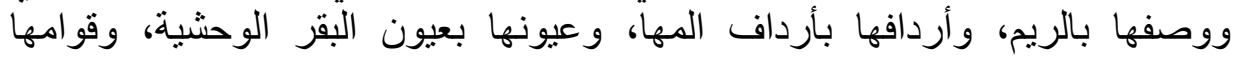

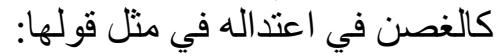

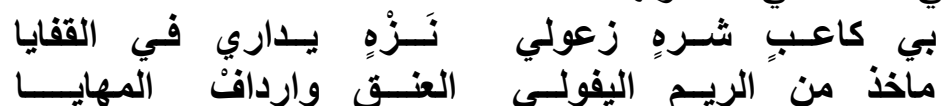

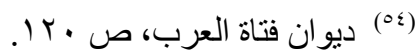

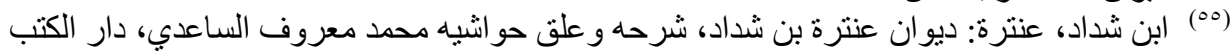

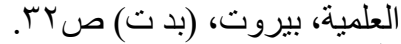

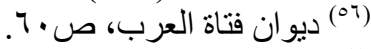

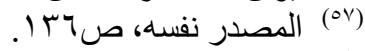
(0)

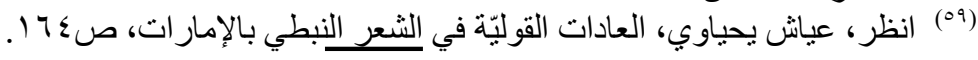




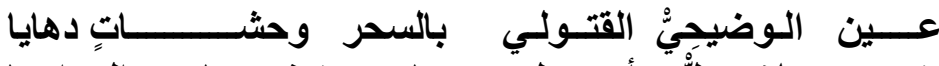

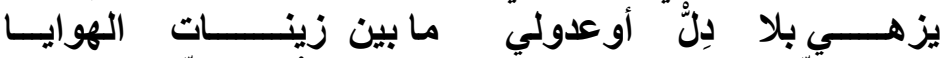

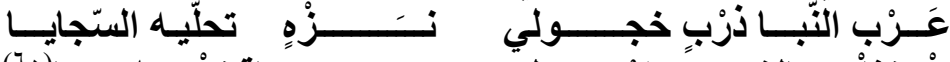

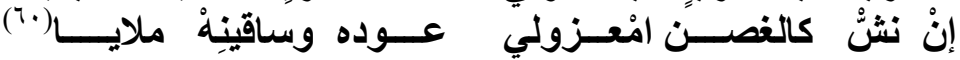

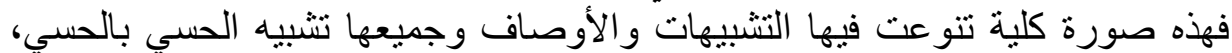

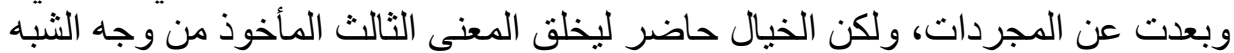

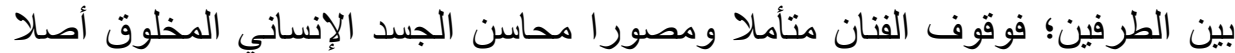

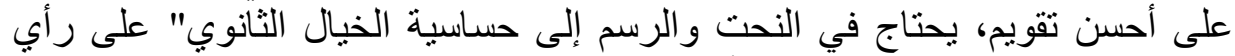

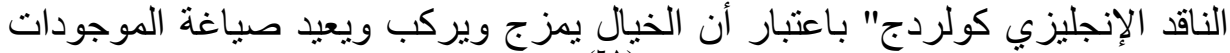

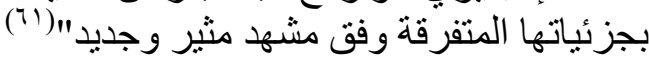

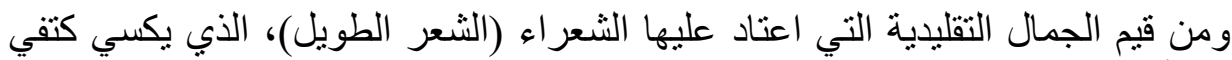

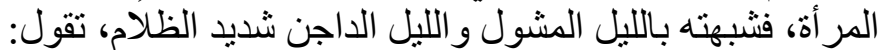

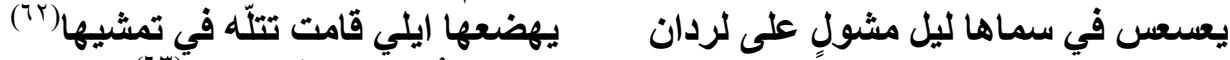

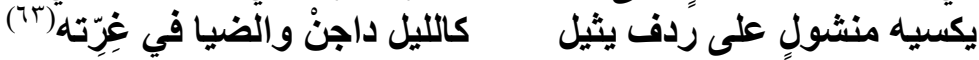
وكذلك تكرر تشبيه جبين المحبوبة بالقمر المضيه، ولئه وخدودها بالورودي:

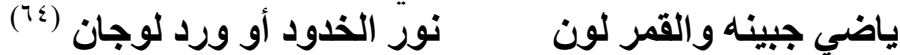

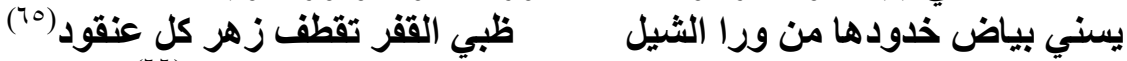

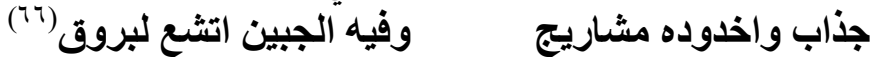

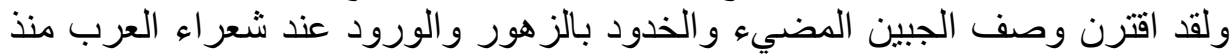
القدم، يقول عمر بن أبي ربيعة:

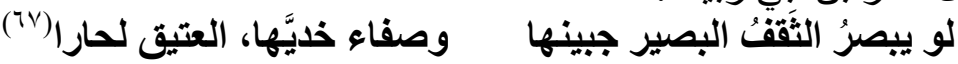

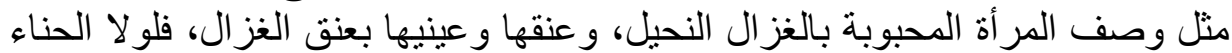

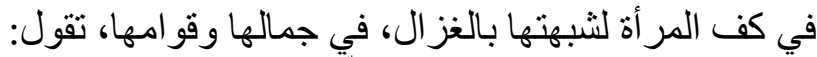

ريم على القيعان لولا التحنّي ل

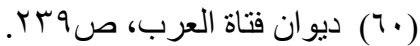

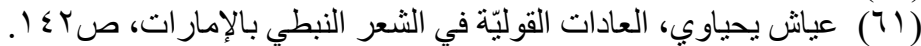

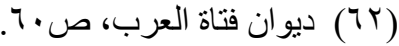

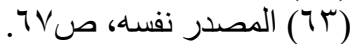

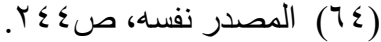

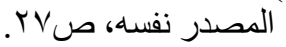

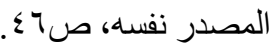

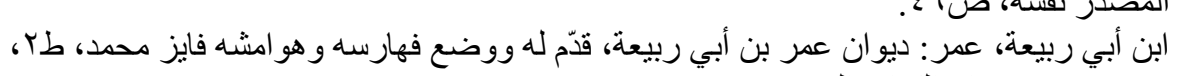


ولقد أثرت البيئة الحضرية تأثثرا واضحا في أسلوب فتاة العرب ولغتها وتتثبيهاتها،

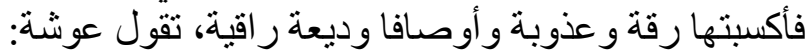

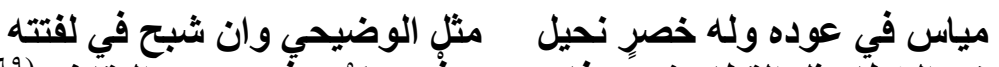

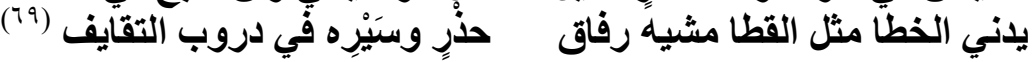

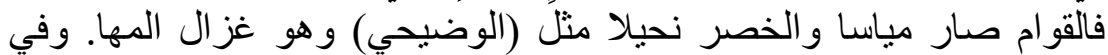

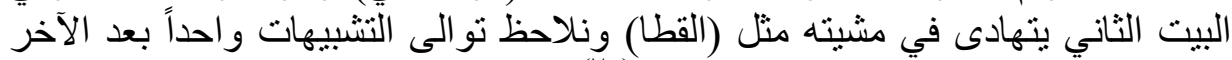

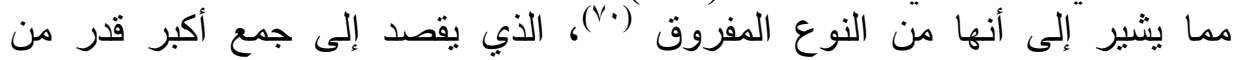

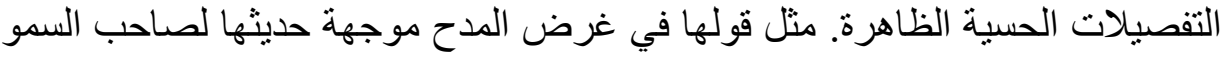
الثيخ محمد بن راشد:

شَدَى الأطيازْ بانغامِ شجيّهِ

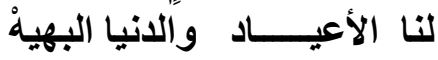
ورمز الفخـــر والنفس الأبيّة

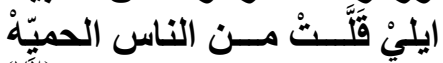

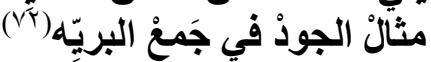

تحية من عبير الورد تثدو

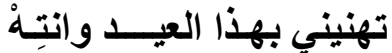

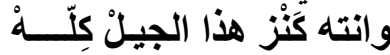

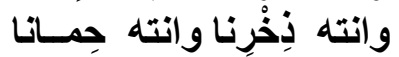

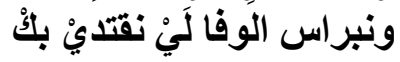

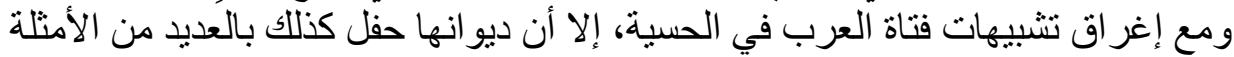

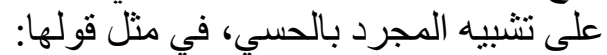

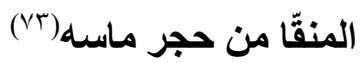

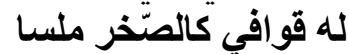

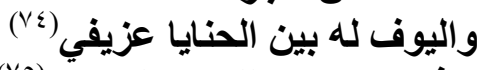

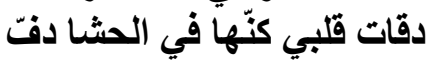

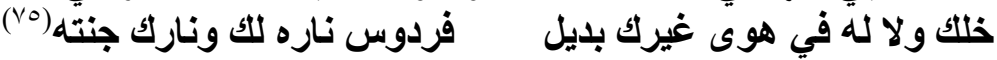

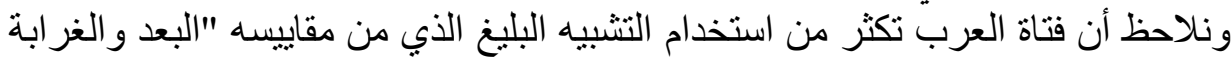

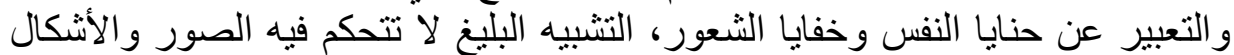

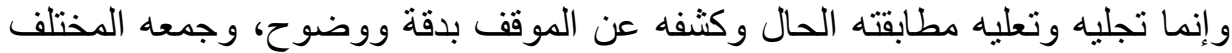

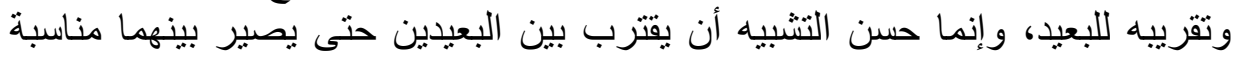

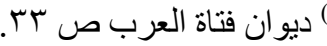

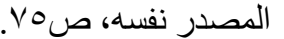

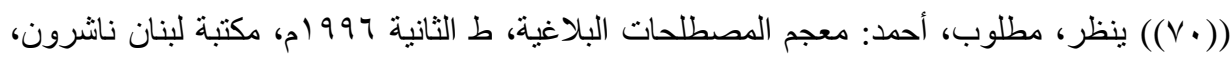




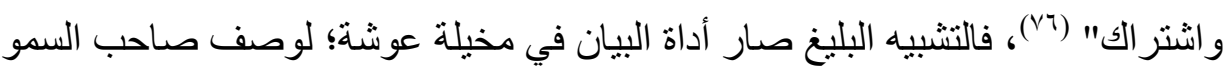

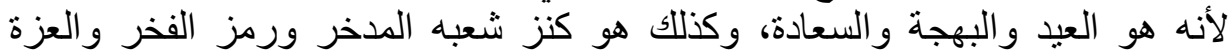

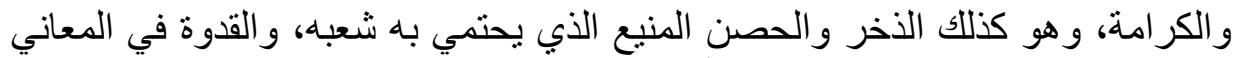

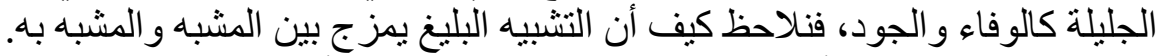

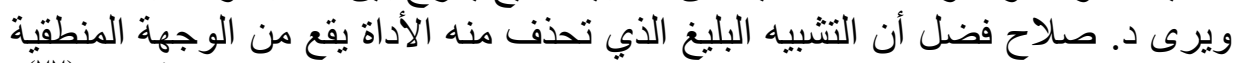

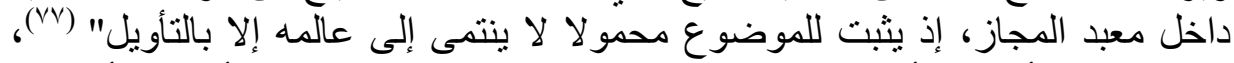

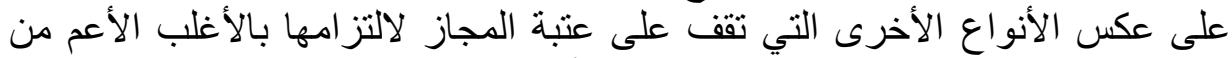

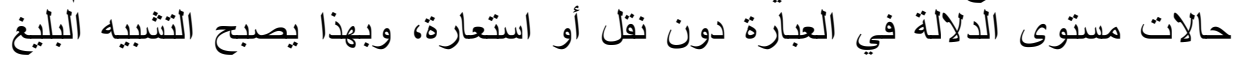

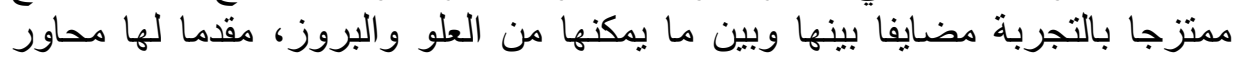

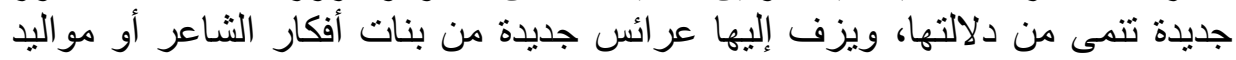

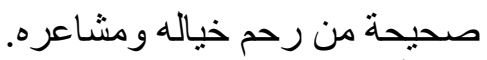
ومن أمثلة ذلك قول فتاة العرب:

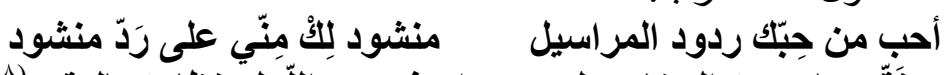

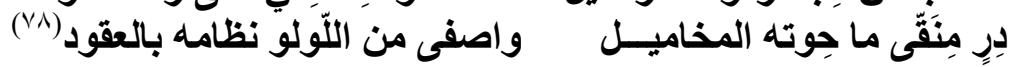

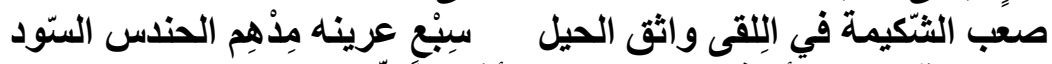

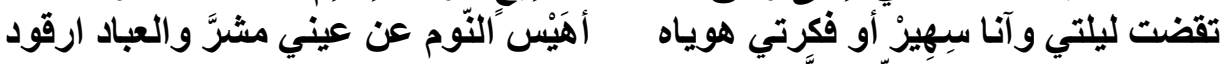

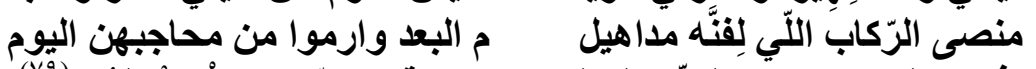

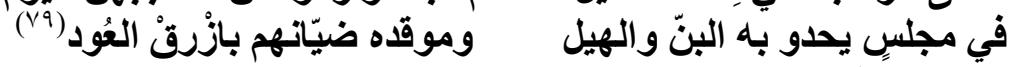

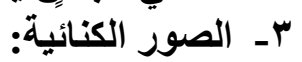

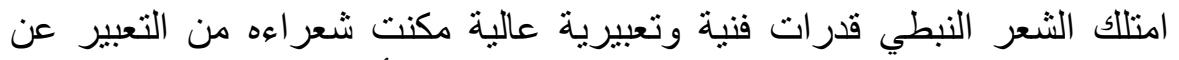

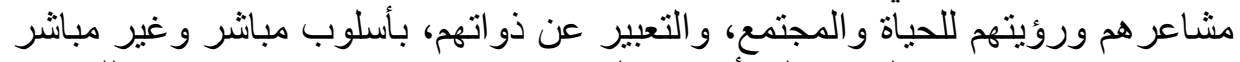

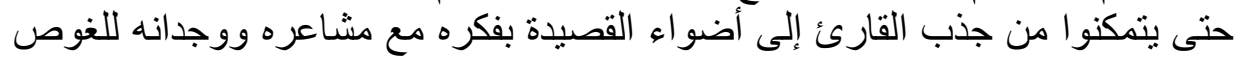

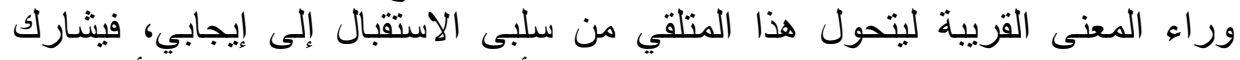

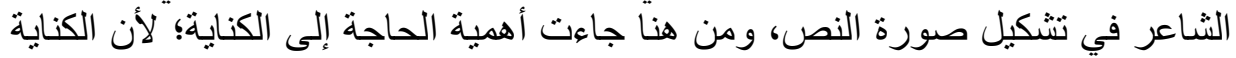

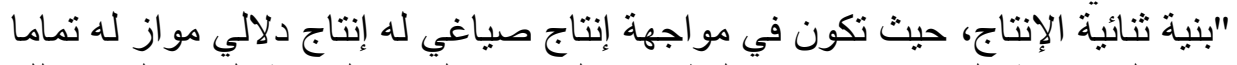

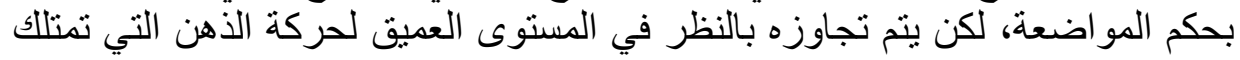
قدرة الربط بين اللوازم والملزومات، فإذا لَّ يتحقق هذا التجاوز فإن المنتج الصياغي التي

ابن رشيق القيرواني: العدة في صناعة الشعر ونقده (VT) (VV)

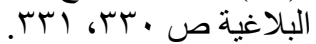

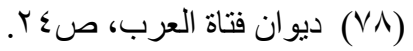
(V9) 
يظل في دائرة الحقيقة"(•).

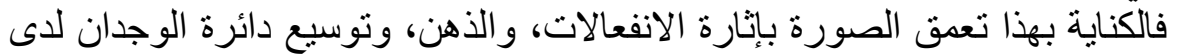

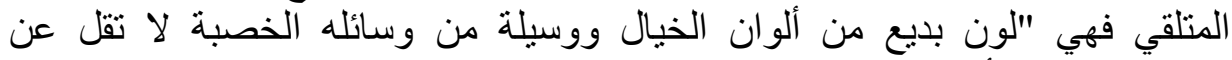

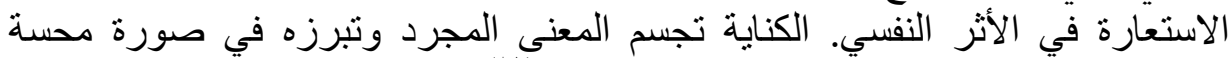

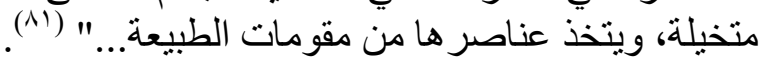

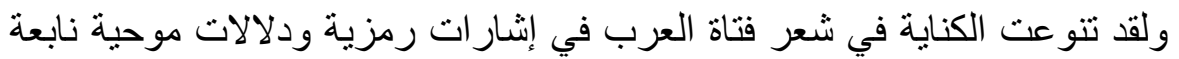

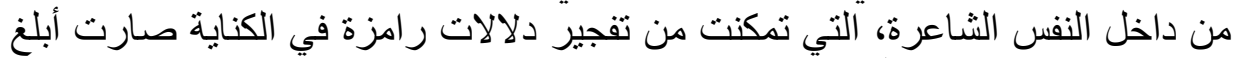

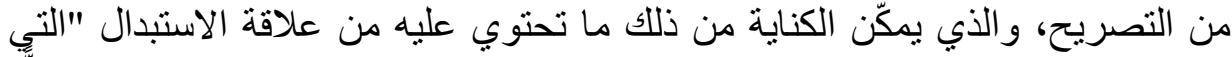

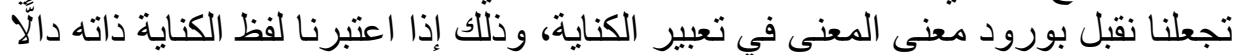

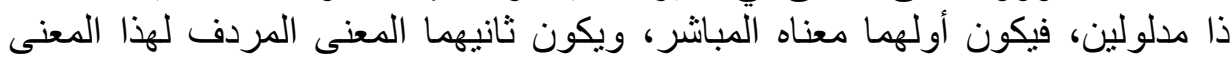

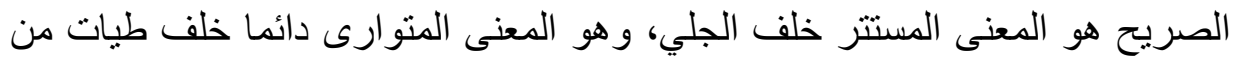

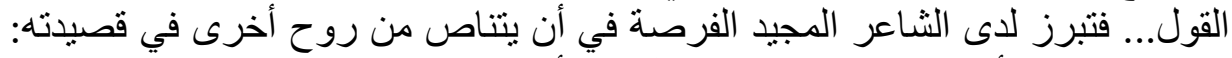

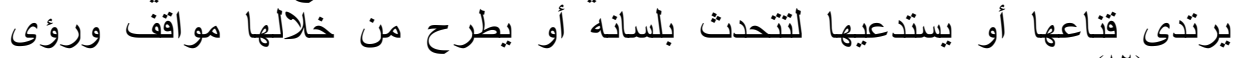
تقنعه" (Ar)

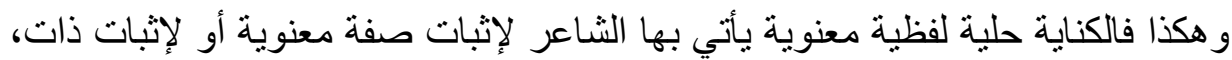

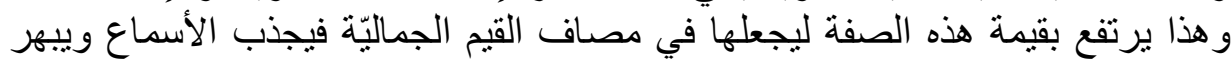
القلوب. ومن أمثلة الكناية المشحونة بالرمز عند فناة فتاة العرب قولها في الرد على قصيدة

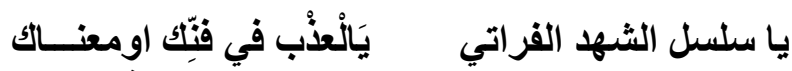

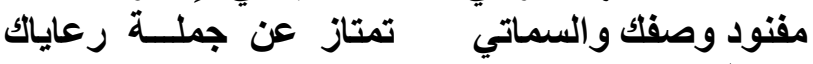

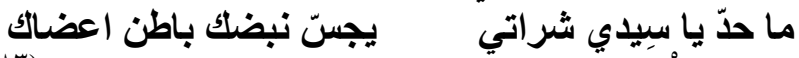

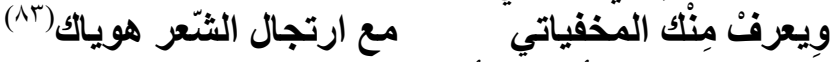

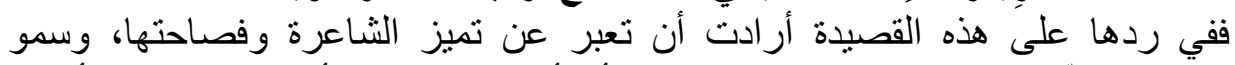

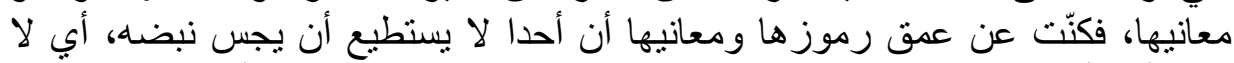

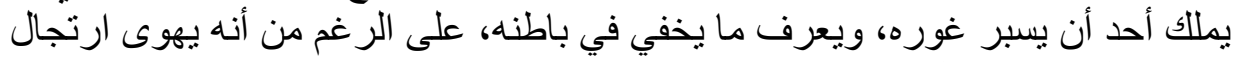
الثعر على رؤوس السامعين.

( • ( ) محمد عبد المطلب: البلاغة العربية قر اعة أخرى، الثركة المصرية العالمية للنشر ، لو نجمان طا . INV ص (199V -

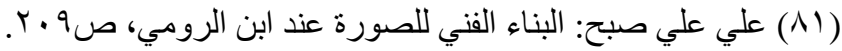

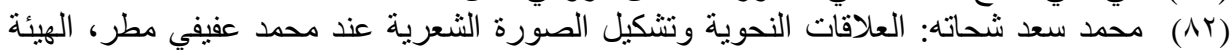

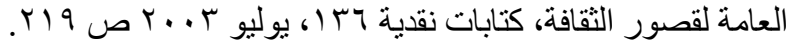


وتضفي الكناية المزيد من الجمال على المعنى والأسلوب، ويتحقق ذلك في قول فتاة العرب في قصيدتها الغنائية التي مطلعها:

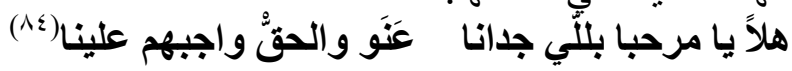

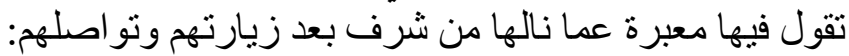

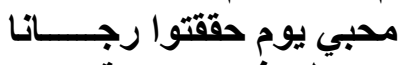

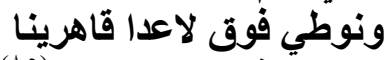

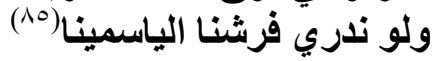

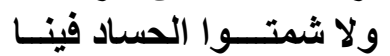

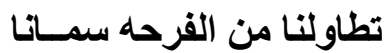

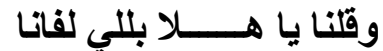

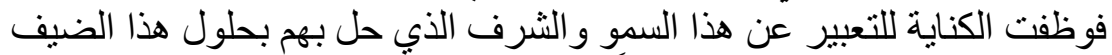

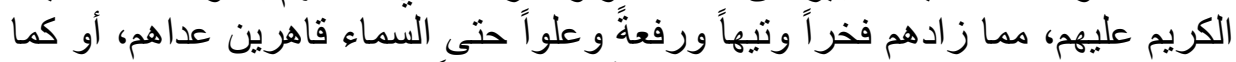

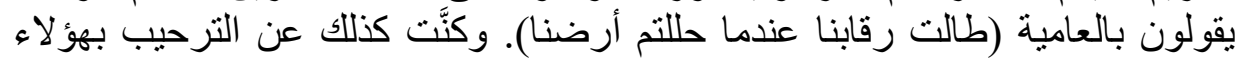

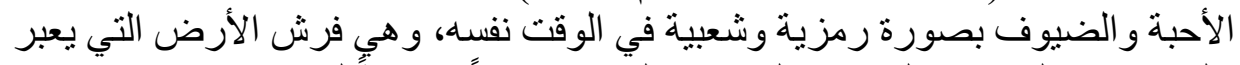

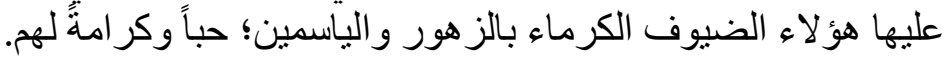

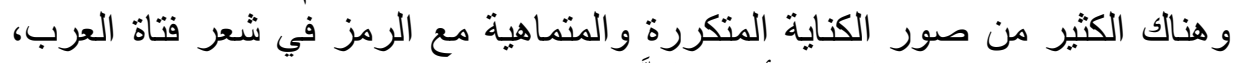

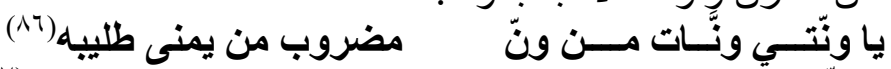

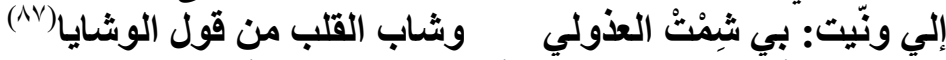

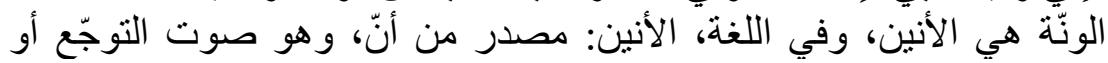

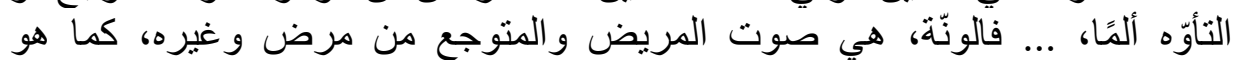

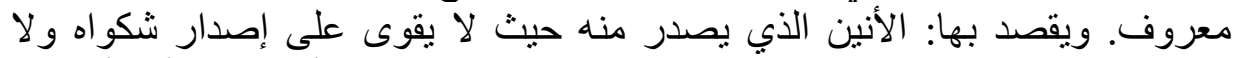

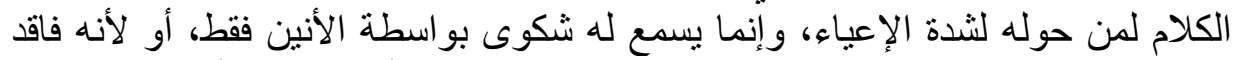

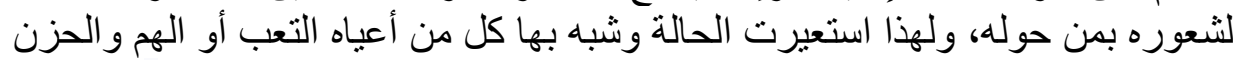

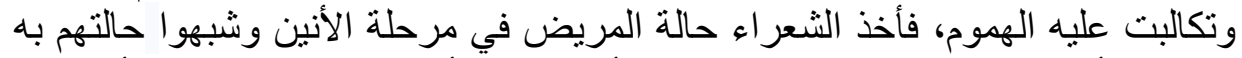

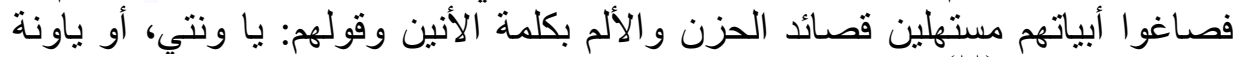

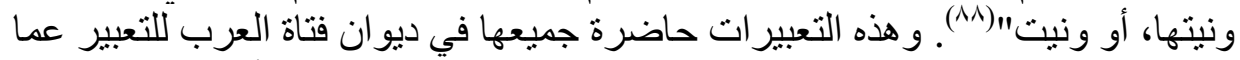

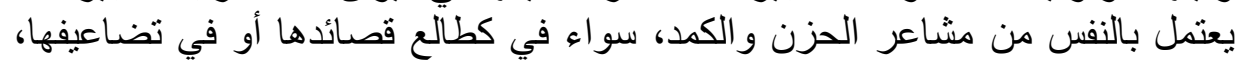

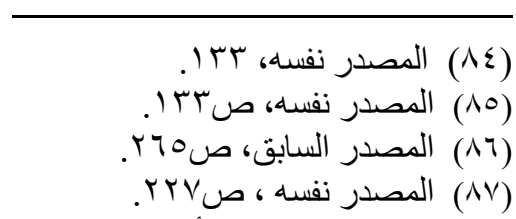

(AN)

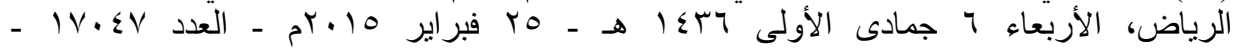
http://www.alriyadh.com/1024849 
كما رأينا في البيتين السابقين، ومثل قولها في مطلع إحدى القصائد:

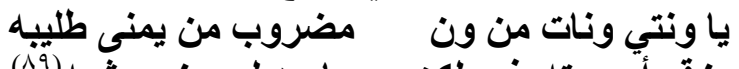

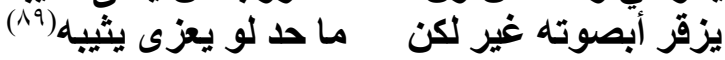

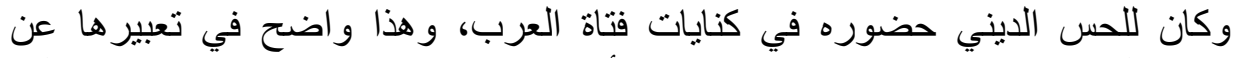

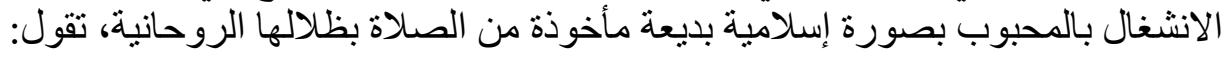

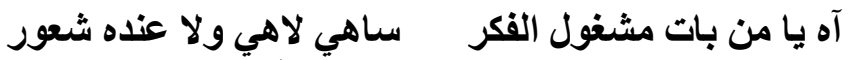

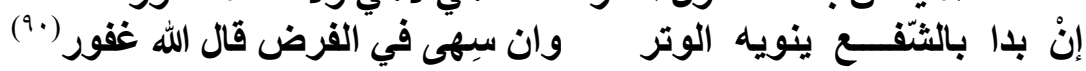

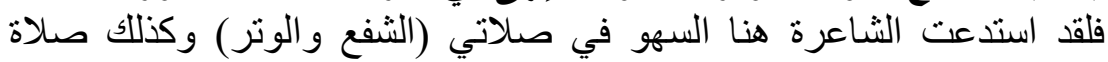

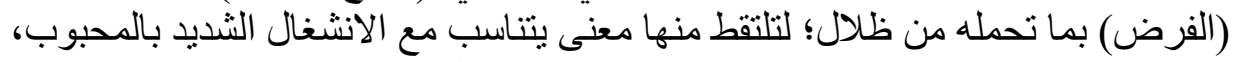

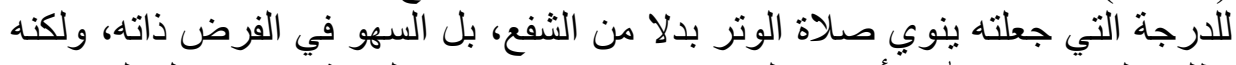

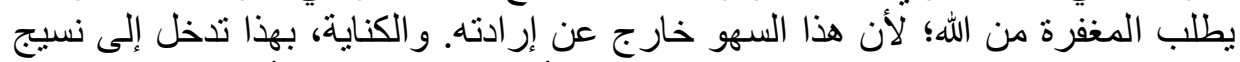

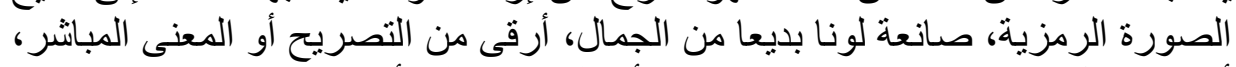

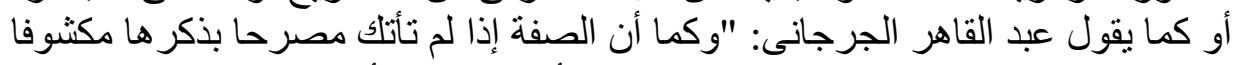

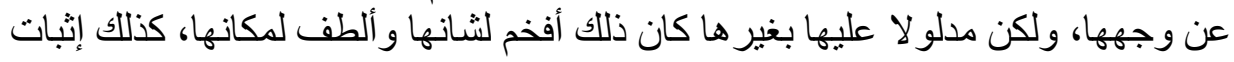

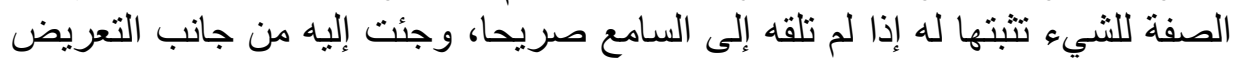

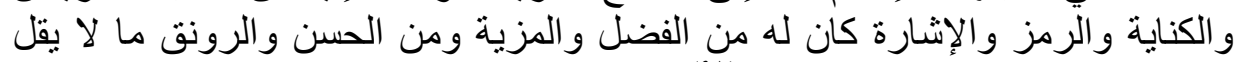

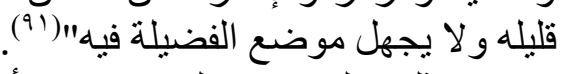

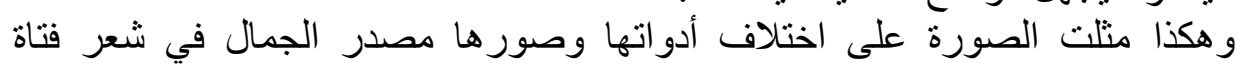

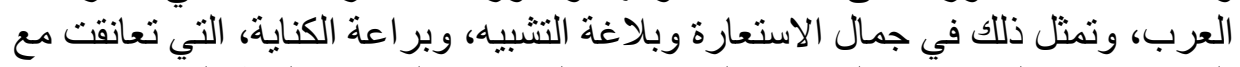

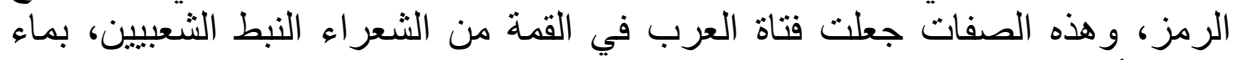
تحقق لأسلوبها من براعة السبك ولمعانيها وصور ها من الخيال العجيب اللعوب الذئي الذئي

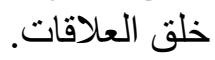

المبحث الثالثـ مصادر الصورة في شعر فتاة العرب:

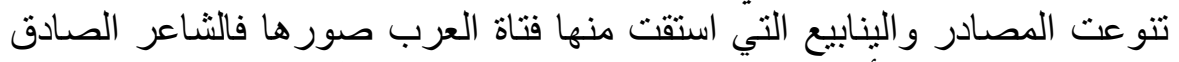

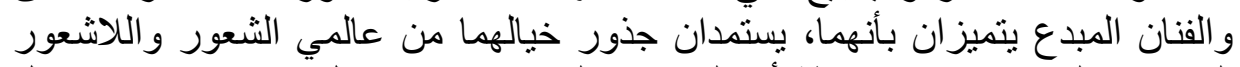

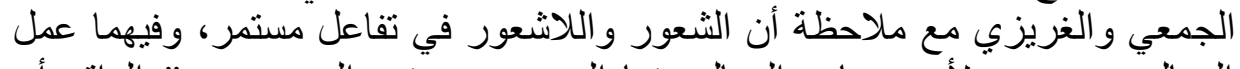

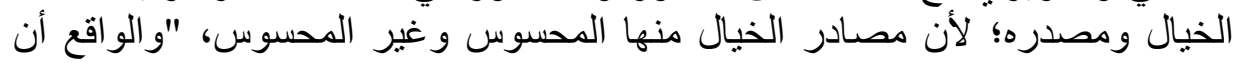

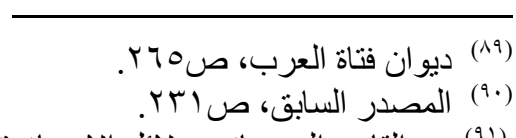

(19) عبد القاهر الجرجانى: دلائل الإعجاز تحقيق محمود شاكر مطبعة المدنى القاهرة، طس، بو 199 ص 


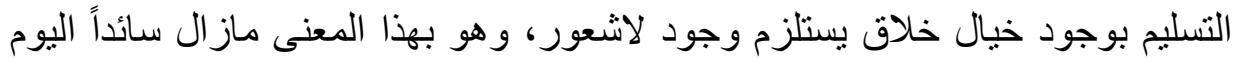

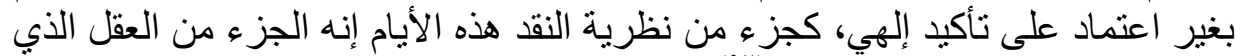

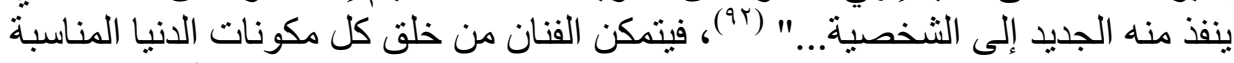

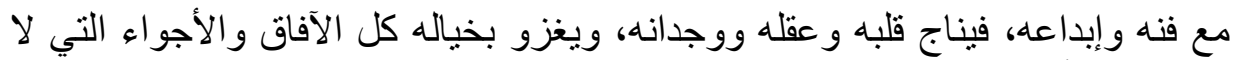

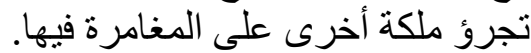

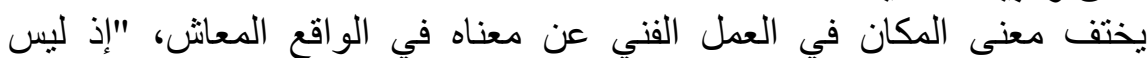

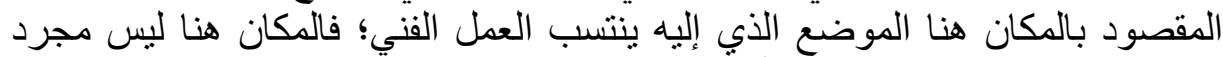

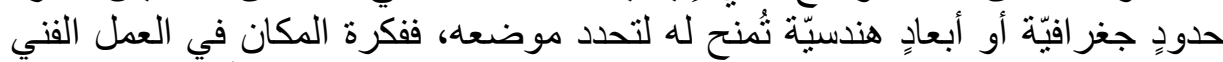

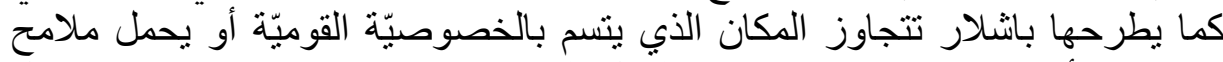

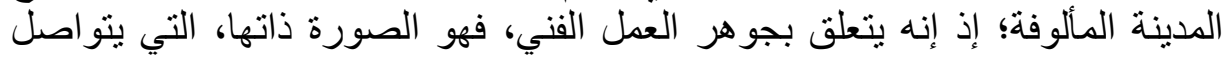

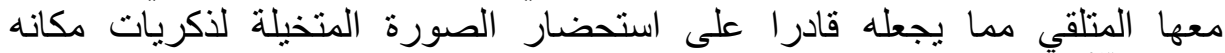
الأليف" مبعه

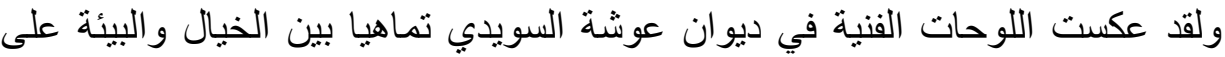

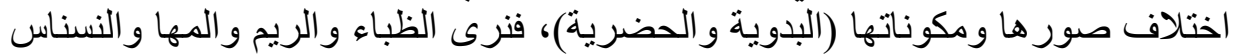

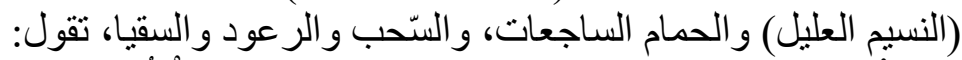

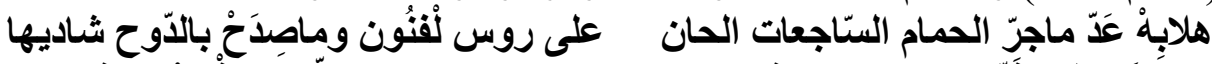

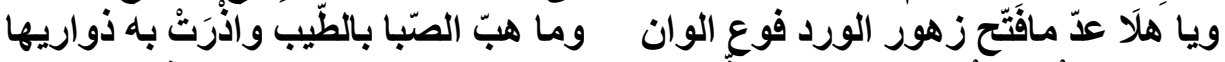

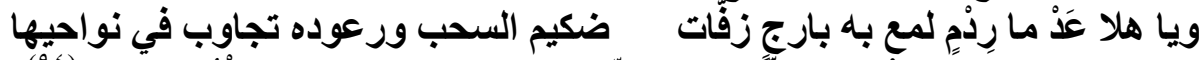

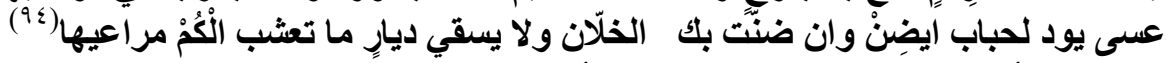

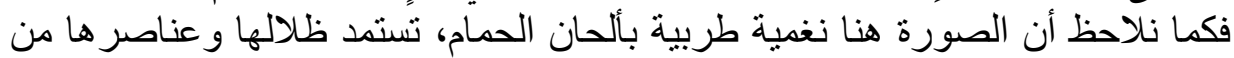

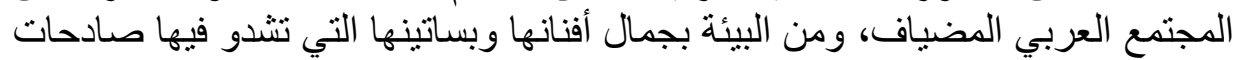

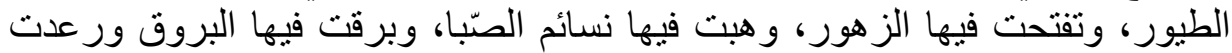

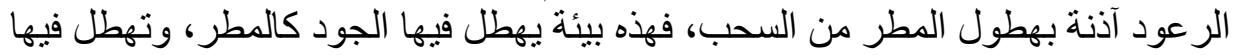

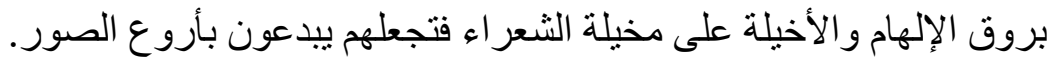

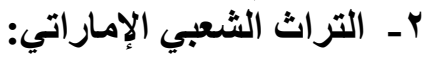

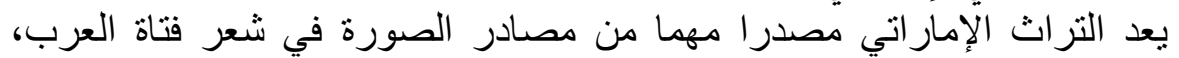
و عملية توظيف الموروث داخل السيّاقات الثعرية هي مسألة غاية في الأهمية؛ ذلك فئ

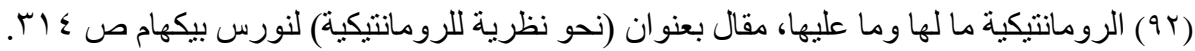

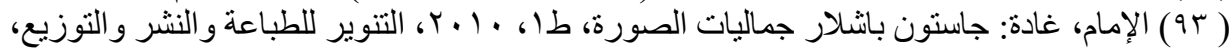

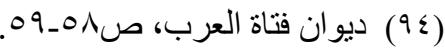




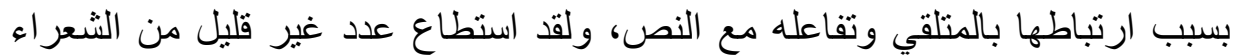

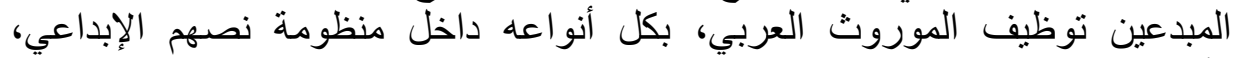

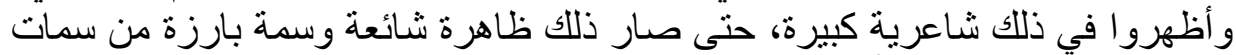

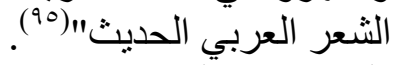

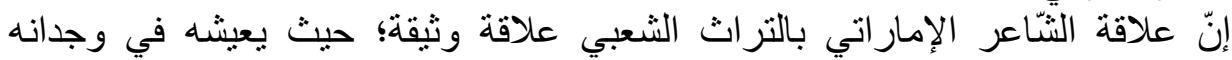

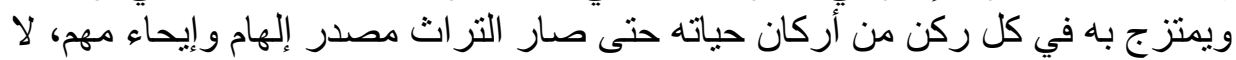

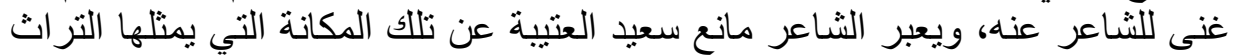

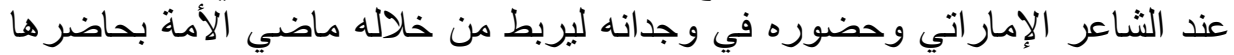

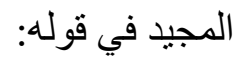
وكنت تردد شعر التراث وتعطي ويحلو لايك العطاء

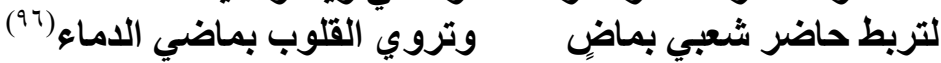

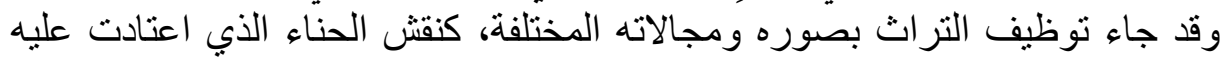

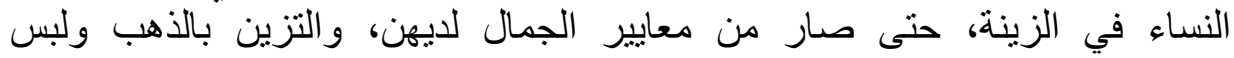
الخلاخيل، تقول:

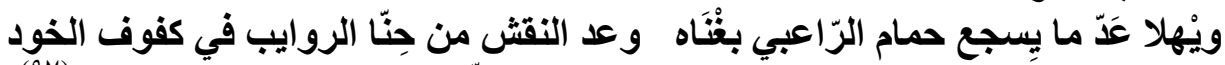

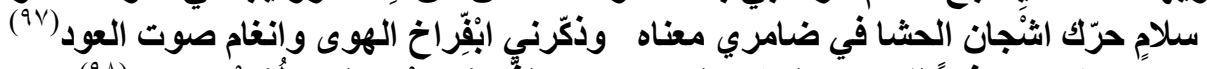

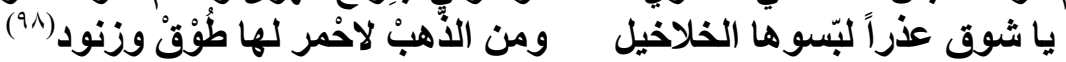

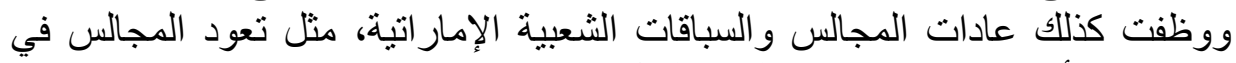

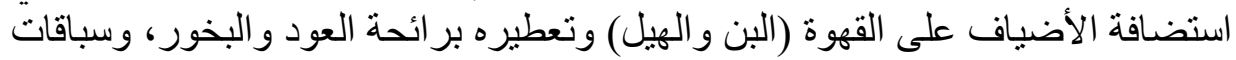
الهجن و الخيول، تقول فتاة العرب:

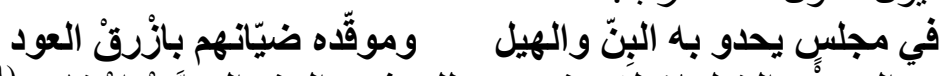

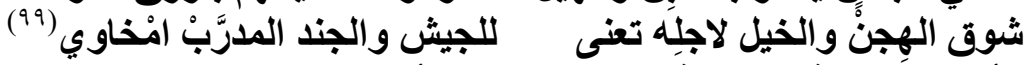

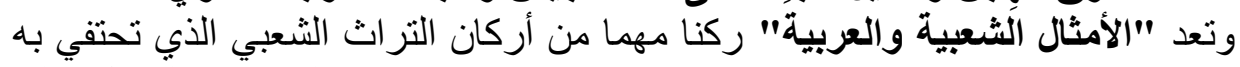

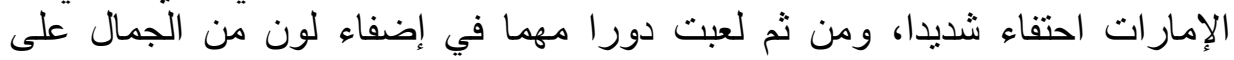

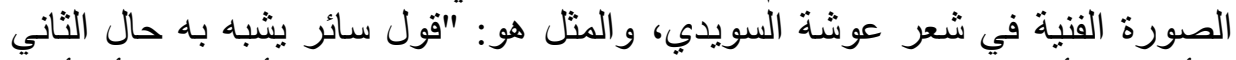
بالأول، والأول فيه التشبيه فقولهم: مثل بين يديه، إذا انتصب، وفئ وفلان أمثل فلان أبي أثنبه

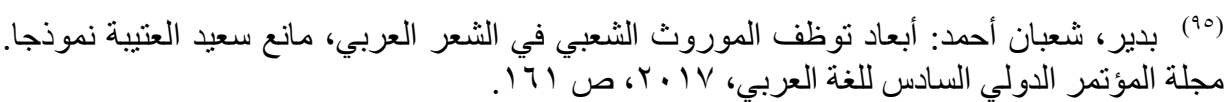

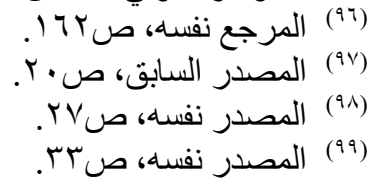




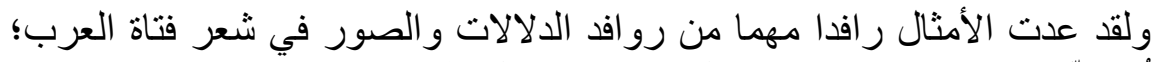

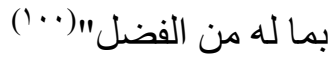

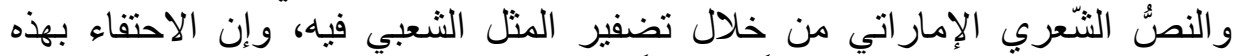

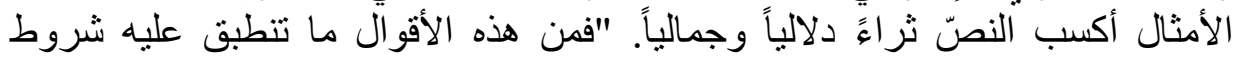

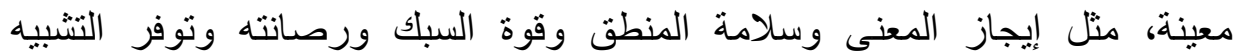

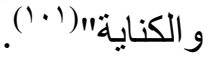
ولقد وظفت الثاعرة الأمثال بصورة صريحة دون تحوير أو تغيير، مما جعله جزءا مهما من اللفظو الدلالة والصورة كذلاعلك، تقول:

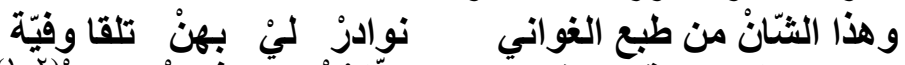

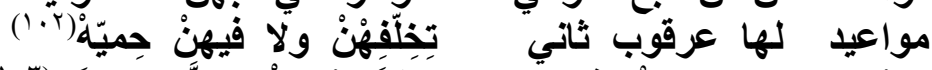

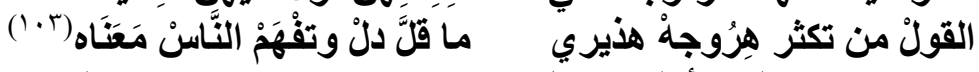

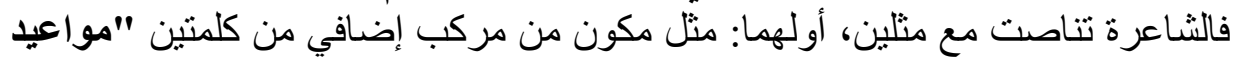

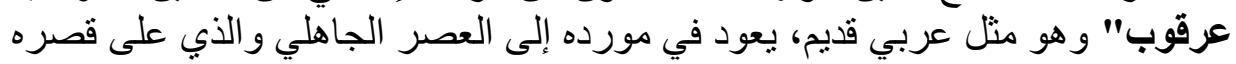

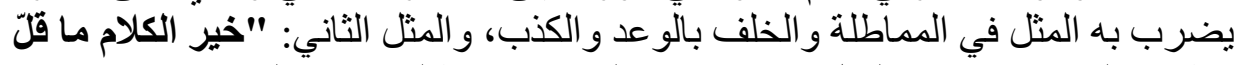
ودل" و الذي يضرب به الدثل في الإيجاز و البعد عن الإطالة وهر جالئل الكلام. بـ التناص والثراء الصورة الثتعرية: استخدمت فتاة العرب التتاص كثية التبرا حتى عد من مظاهر الجمال في الصور

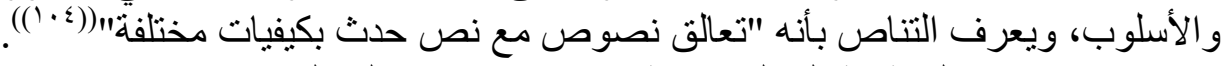

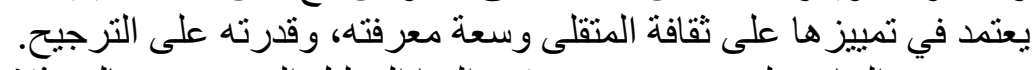

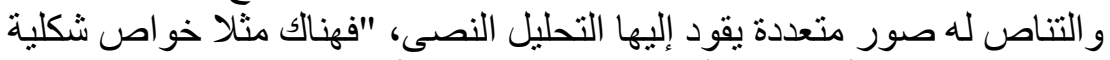

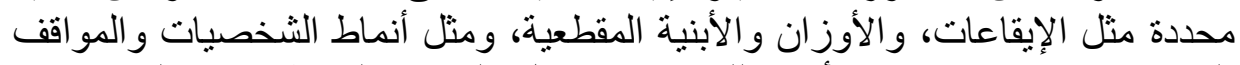

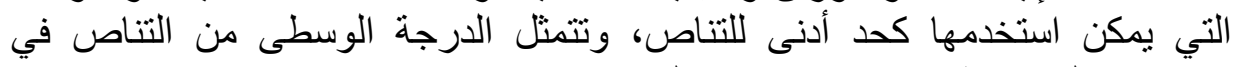

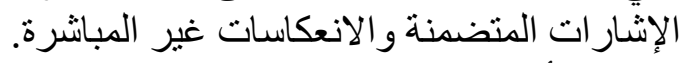

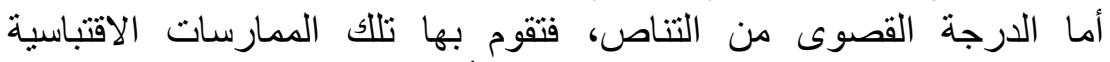
و المعارضات، مما يحيل على مجموعة الثفر اتل الأسلوبية والبلاغية المستخدمة في الثيان

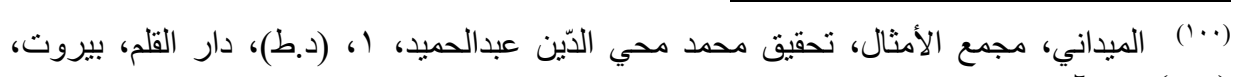

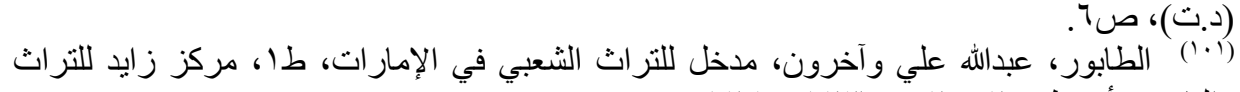

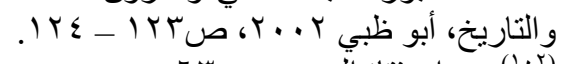

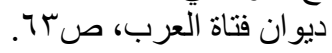

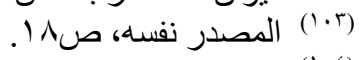

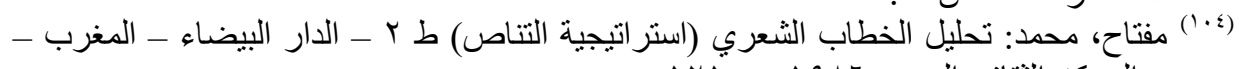
AV

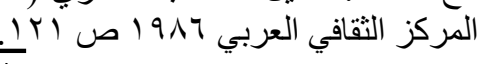


نصوص سابقة بشكل لا يمكن أن يخفي على القارئ المتوسط، وهو المجال الذي تمثلك

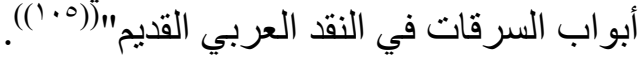

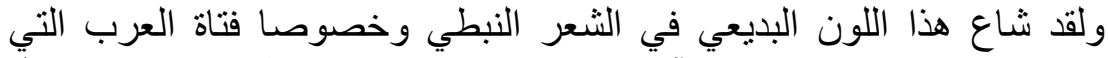

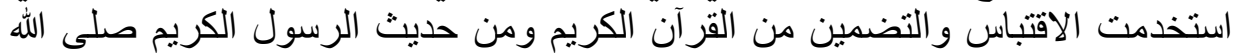

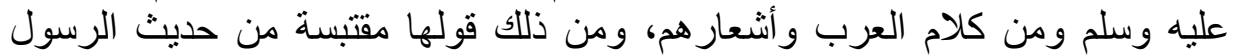

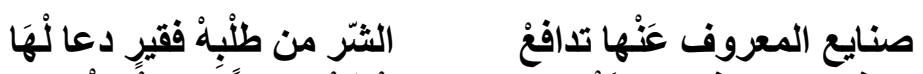

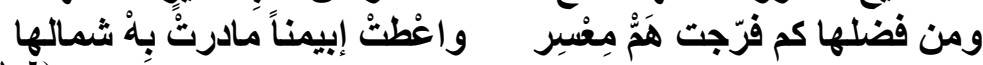

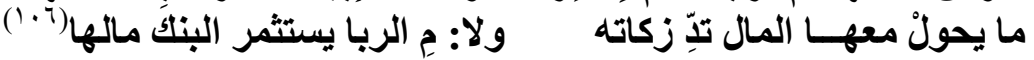

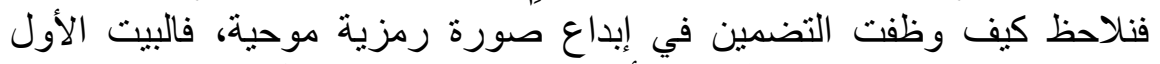

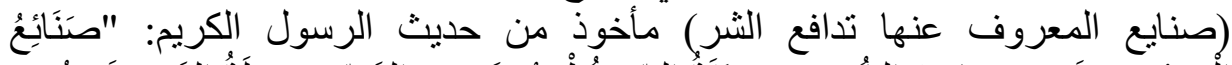

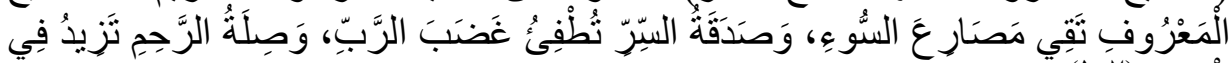

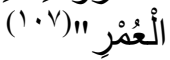
وكذلك المعنى في البيت الثاني الذب رسمته بريشة الاستعارة، مستوحى من حديث

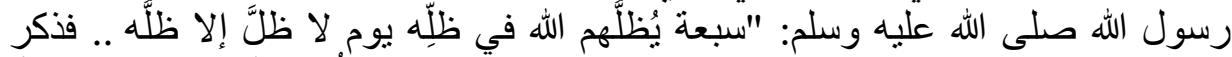

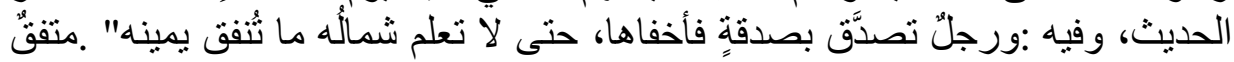
عليه.

بل إنها لا تكتفي بتوظيف التناص بهذا الجمال الفني، فجاءت في البيت الثالث

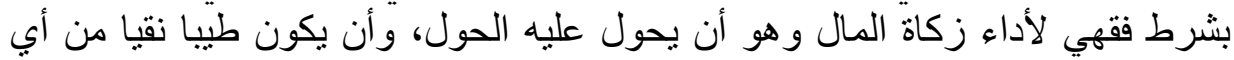

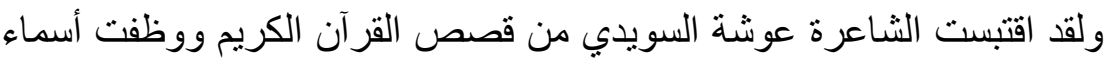

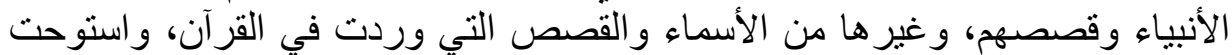

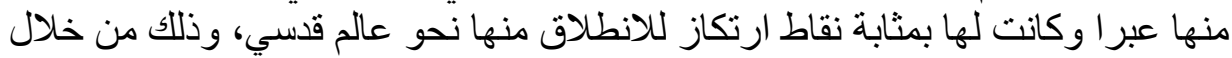

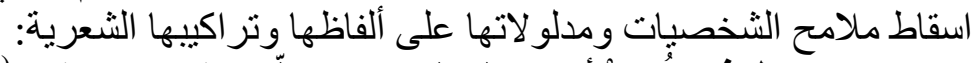

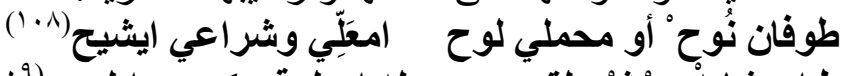

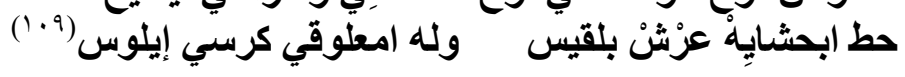

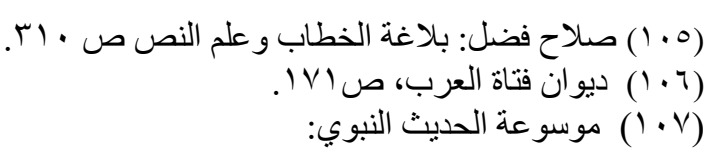
https://ainpedia.com/article/\%D8\%B5\%D9\%86\%D8\%A7\%D8\%A6\%D8\%B9\%D8\%A7\%D9\%84\%D9\%85\%D8\%B9\%D8\%B1\%D9\%88\%D9\%81 


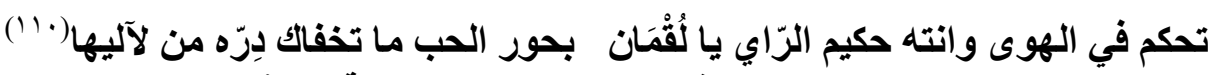

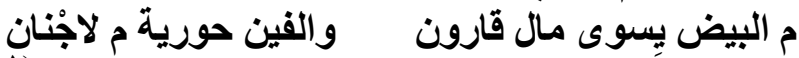
لو لو ظو ظهر في اللي يعبدون

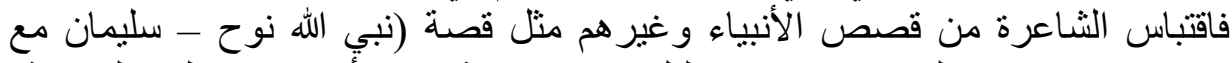

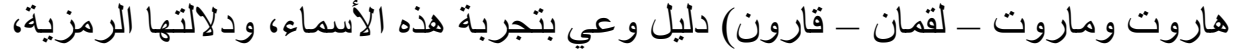

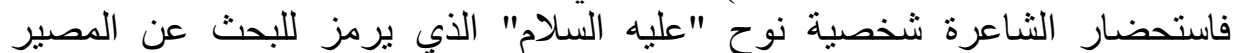

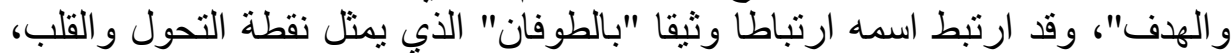

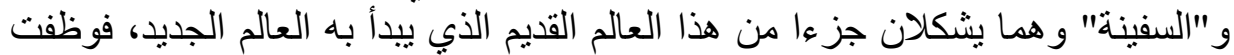

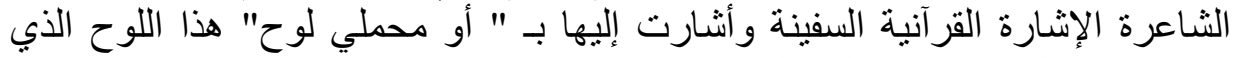

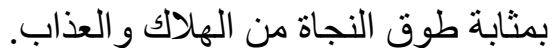

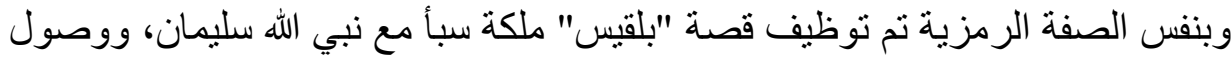

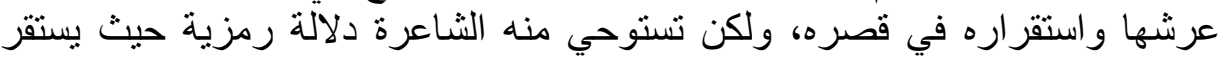

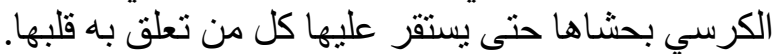

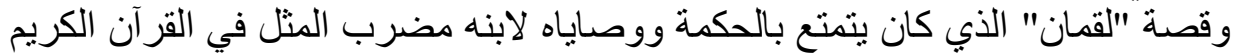

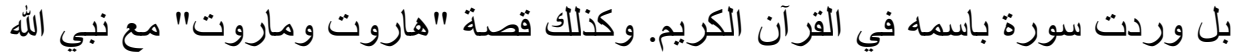

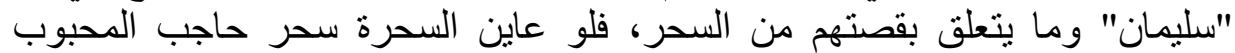

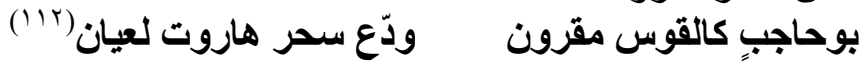

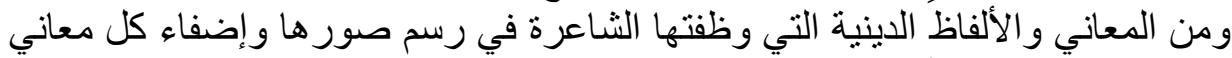

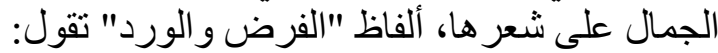

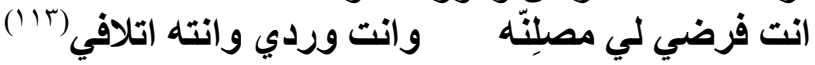

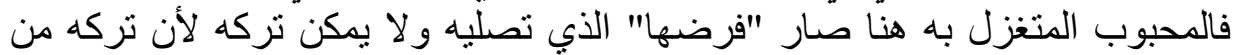

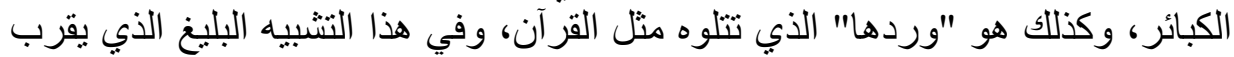

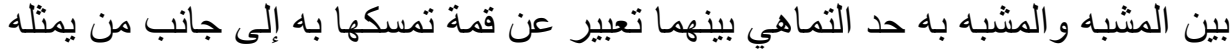

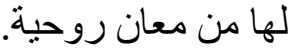
كذلك استوحت فتاة العرب صور هاء من قصص الثعر اء العانققين مثل "قيس وليلى" بما تحمله من ظلال و إيحاءات، تقول:

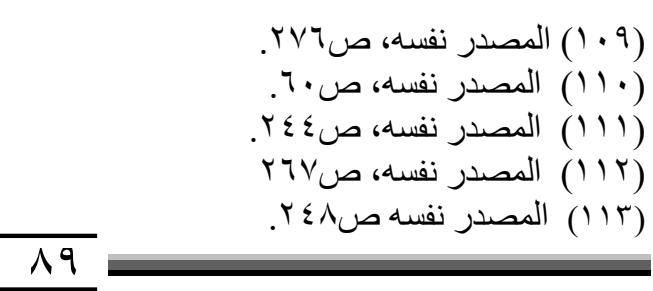




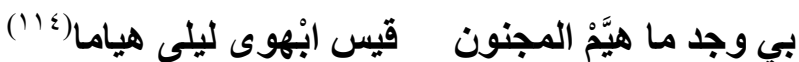

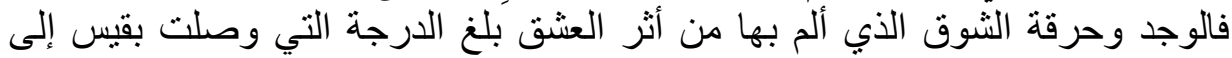
الجنون، عندما هام بحب ليلى هياما.

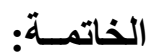

وبعد رحلة الجمال الممتعة في شعر فتاة العرب انتهى البحث إلى بعض النتائج

ا ـ أن الشعر النبطي البدوي، هو شعر شعبي، اكتسب شعبيته من انتشاره في الأوساط

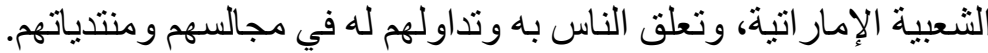

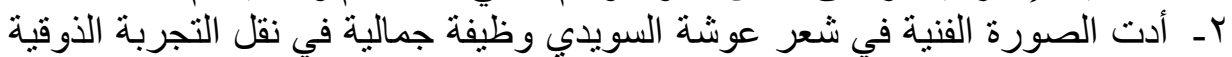

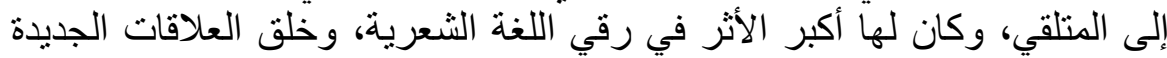
داخل بنية الصورة و الدلالة. r- انعكست الوظيفة الجمالية للصورة فئة في ديوان فتاة العرب على العى جمال الوصف،

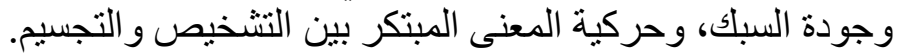

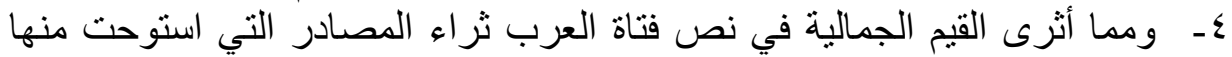

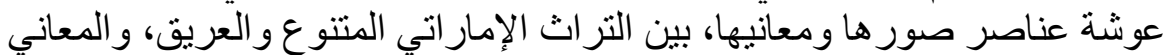

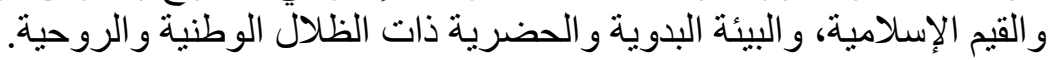




$$
\text { أولا - المصادر البحث ومر اجعه: }
$$

السويديّ، عوشة بنت خليفة، ديوان فتاة العرب، جمع وتقديم حمد خليفة أبو شهاب،

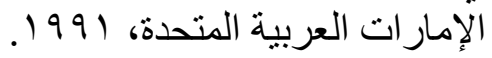

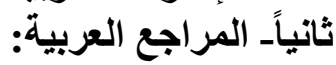

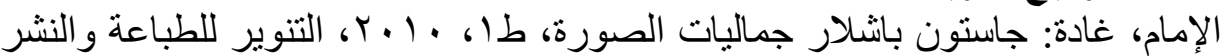

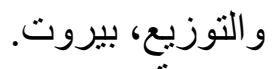

ابن أبي ربيعة، عمر : ديوان عمر بن أبي أبي ربيعة، قدّم لله ووضع فهارسه وهو امشه فايز

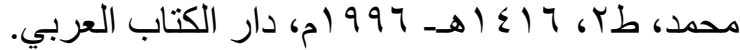

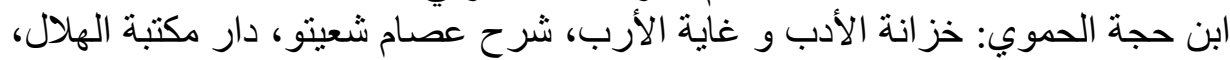

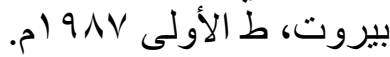
ابن رشيق القيرواني: العمدة في محاسن الثعر وآداديه آدابه ونقده، تحقيق محمد محي الدين

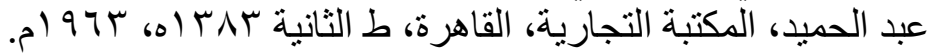

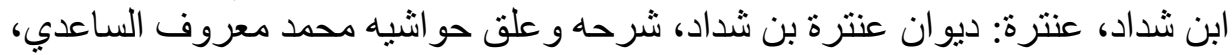

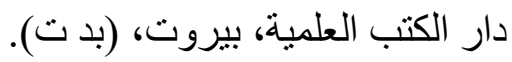

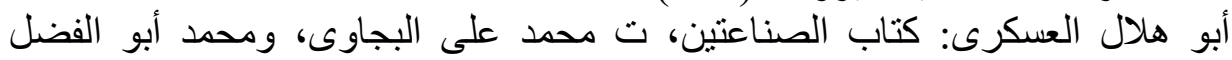

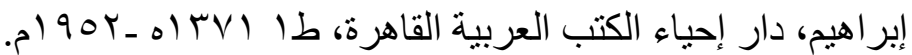
بدير، شعبان أحمد: أبعاد نوظف المواء الموروث الثربة الثعبي في الثعر العربي، مانع سعيد العتيبة

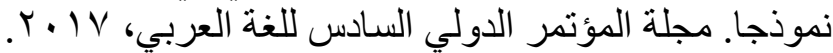

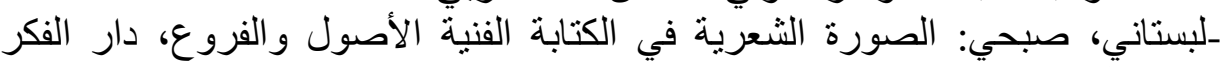

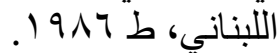
التطاوي، عبد الله: الصورة في شعر مسلم بن الوليد، ط دار غريب للطبع والنشر،

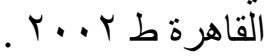

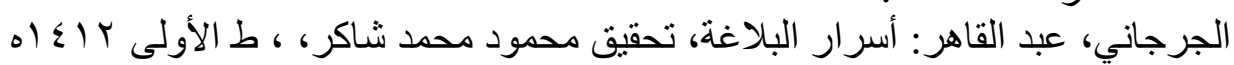

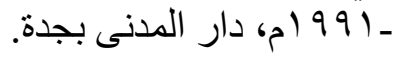
ل: : دلائل الإعجاز تحقيق محمود شاكر مطبعة المدنى القاهرة، طس، .1994 الحسن، غسّان: الثُعر النبطي وشعر الفصحى تراث واحد واحد دراسة في علاقات الثعر

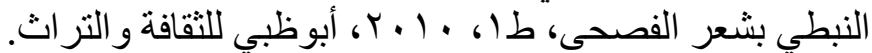

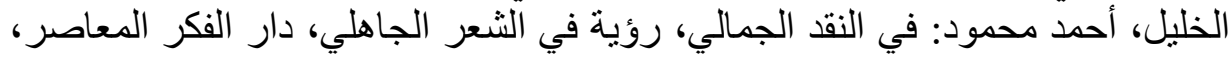

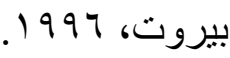
الديدي، عبد الفتاح: علم الجمال، مكتبة الأنجلو المصرية، القاهرة، (1919 . 
رسلان، صلاح الدين بسيوني: القيم في الإسلام (بين الذاتية و الموضوعية)، دار الثقافة

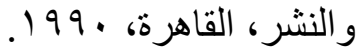

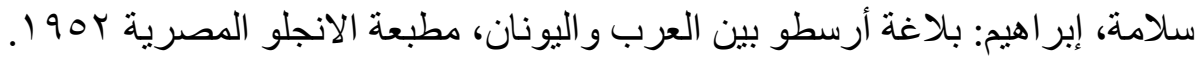

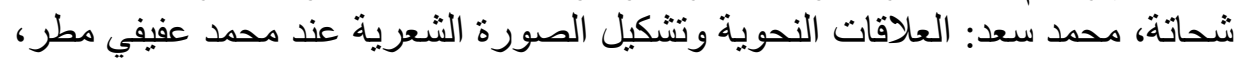

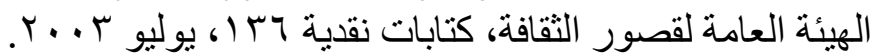

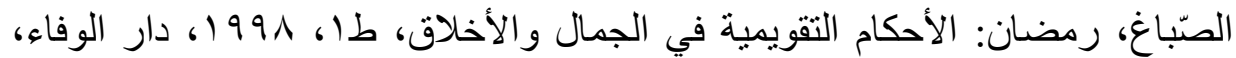

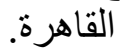
صبح، علي علي: البناء الفني للصورة عند ابن الرومى، ط 997 (ا، المكتبة الأزهرية

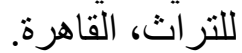
-ضيف، شوقي: في النقد الأدبي، ط السادسة، دار المعارف القان القاهرة.

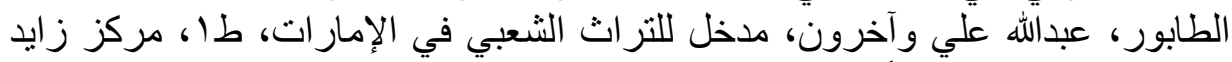

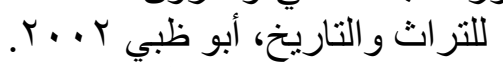

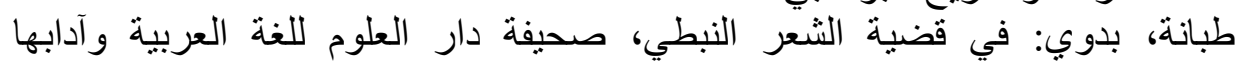

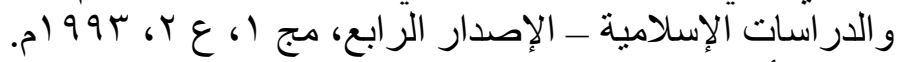

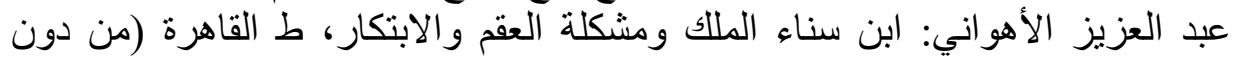
تاريخ). عبد الغني بركة: بين البلاغة القديمة و النقد الحديث، ط دار الطباعة المحمدية، القاهرة

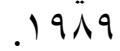
عبدالله، محمد حسن: الصورة و البناء الثعري، ط دار المعار المعارف.

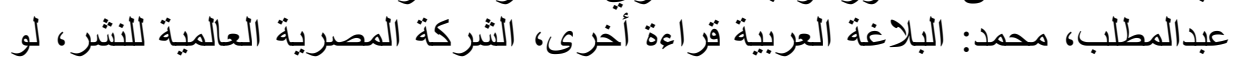

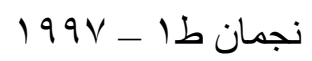

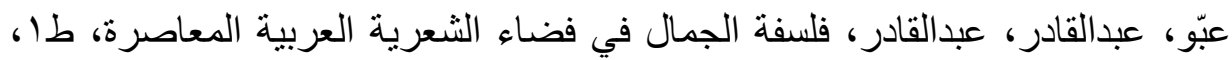

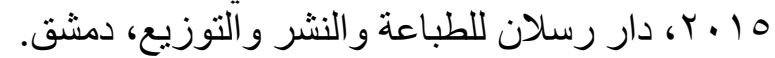

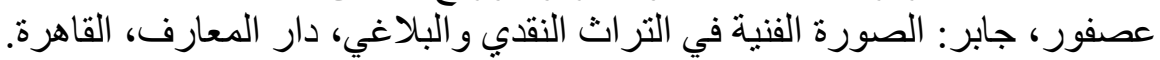

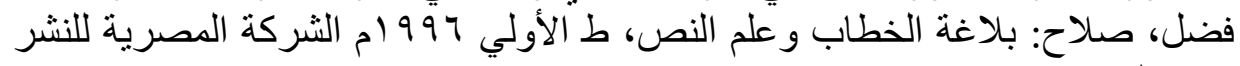
لونجمان.

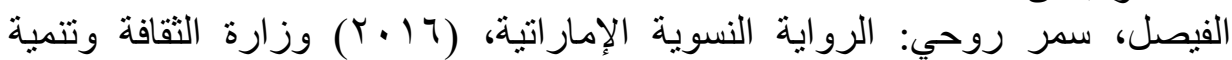
المعرفة.

قنشوبة، أحمد: في أنواع الشعر الثعبي، صحيفة دار العلوم للغة العربية وآدابها

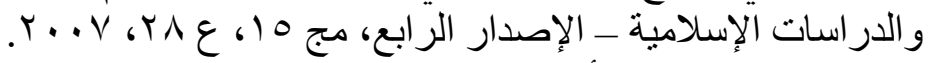

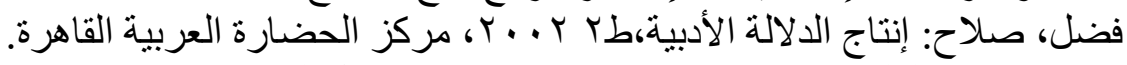
مرتاض، عبدالملك: بنية اللغة في الثعر النبطي، تحليل لنص قصرئ النيدة "سلام يا شيخ" 


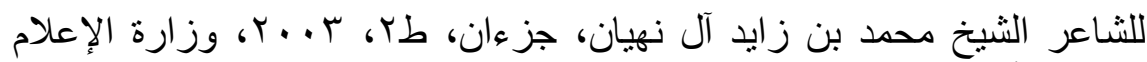
والثقافة، أبوظبي.

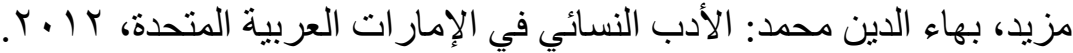

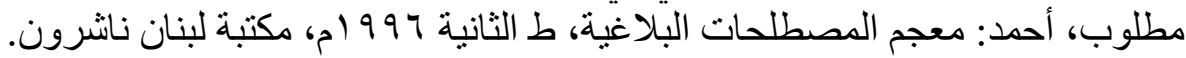

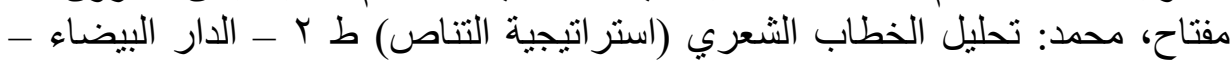

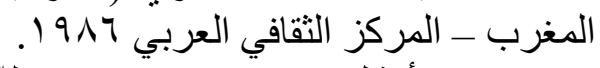

الميداني، مجمع الأمثال، تحقيق محمد محي الدّين عبدالحميد، ال، (د.ط)، دار القلم،

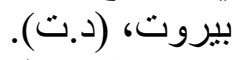

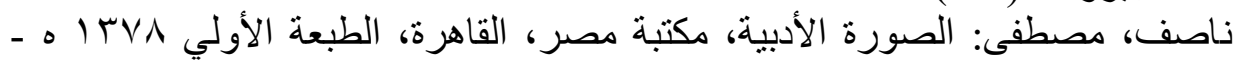

$$
\text { 1901 }
$$

نصر، عاطف جودة: الخيال مفهوماته ووظائفه، ط الهيئة المصرية العامة للكتاب،

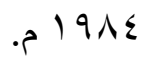

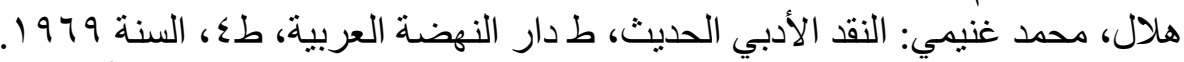

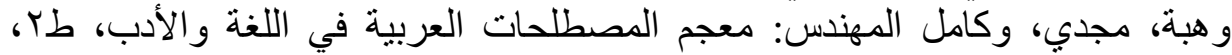

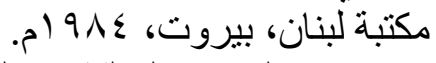

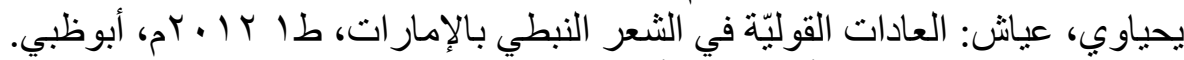

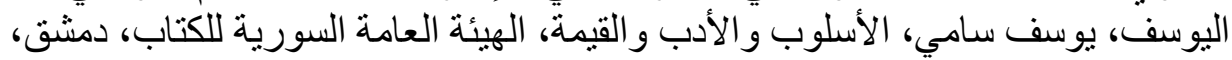

$$
r+11
$$

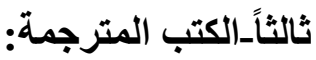

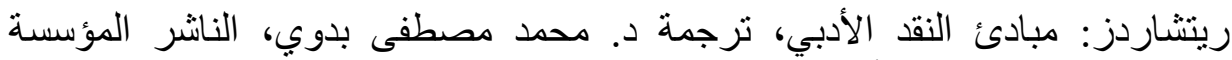

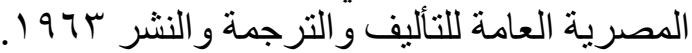

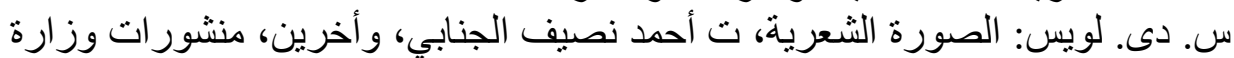

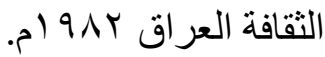

رابعا - الرسائل الجامعيّة:

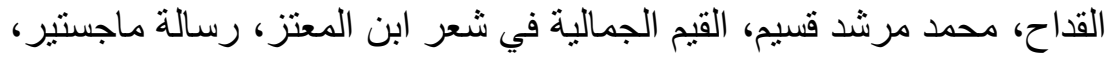

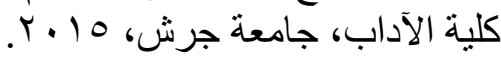

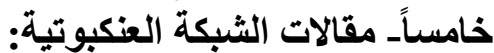

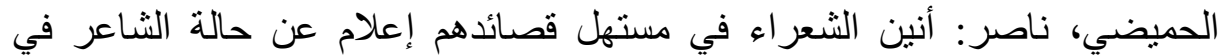

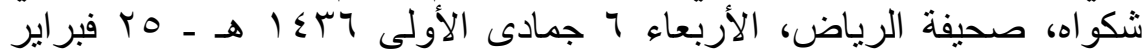

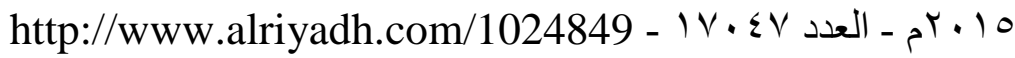
القاضي، عبد العزيز، سياحة في بيت عود ريحان، صحيفة الجزيرة السعودية، الإثنين https://www.al$r \cdot r$.

يناير 
jazirah.com/2020/20200113/tr1.htm

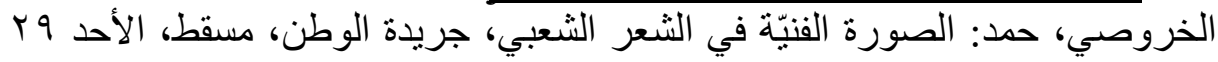

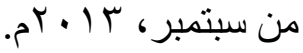

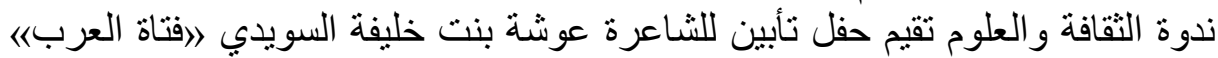

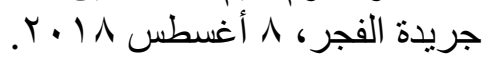

